\title{
$1 \quad$ Mating system of Ustilago esculenta and its polymorphism
}

2 Syun-Wun Liang*†

3 Yen-Hua Huang ${ }^{\dagger}$

$4 \quad$ Jian-Ying Chiu $^{\dagger}$

5 Hsin-Wan Tseng*

6 Jin-Hsing Haung ${ }^{\ddagger}$

7 Wei-Chiang Shen ${ }^{* 1}$

8

9 *Department of Plant Pathology and Microbiology, National Taiwan University,

10 Taipei 10617, Taiwan, ROC

$11{ }^{\dagger}$ Institute of Biomedical Informatics and Center for Systems and Synthetic Biology,

12 National Yang-Ming University, Taipei 11221, Taiwan, ROC

$13{ }^{\ddagger}$ Plant Pathology Division, Taiwan Agricultural Research Institute, Taichung 41362,

14 Taiwan, ROC

15

$16{ }^{1}$ Corresponding author:

17 Wei-Chiang Shen

18 Department of Plant Pathology and Microbiology

19 National Taiwan University

20 No. 1, Sec. 4, Roosevelt Rd., Taipei 10617, Taiwan, ROC

$21 \quad$ E-mail: wcshen@ntu.edu.tw

22

23

24 Running title: U. esculenta is bipolar and multiallelic

25

26 


\section{ABSTRACT}

Zizania latifolia Turcz., which is mainly distributed in Asia, has had a long cultivation history as a cereal and vegetable crop. On infection with the smut fungus Ustilago esculenta, Z. latifolia becomes an edible vegetable, water bamboo. Two main cultivars, with a green shell and red shell, are cultivated for commercial production in Taiwan. Previous studies indicated that cultivars of Z. latifolia may be related to infection with $U$. esculenta isolates. However, related research is limited. The infection process of the corn smut fungus Ustilago maydis is coupled with sexual development and under control of the mating type locus. Thus, we aimed to use knowledge of $U$. maydis to reveal the mating system of $U$. esculenta. We collected water bamboo and isolated 145 U. esculenta strains from Taiwan's major production areas. By using PCR and idiomorph screening among meiotic offspring and field isolates, we identified three idiomorphs of the mating type locus and found no sequence recombination between them. Whole-genome sequencing (Illumina and Pacbio) suggested that the mating system of $U$. esculenta was bipolar. Mating type locus 1 (MAT-1) was 555,862 bp, and contained 44\% repeated sequences. Sequence comparison revealed that $U$. esculenta MAT-1 shared better conservation with the sex chromosome of $U$. maydis than $U$. hordei. These results can be utilized to further explore the genomic diversity of $U$. esculenta isolates and their application for water bamboo breeding. heterothallism, mating type locus 


\section{INTRODUCTION}

Water bamboo is one of the most popular vegetables in Asia. When the wild rice Zizania latifolia Turcz. is infected by the smut fungus Ustilago esculenta, tumor-like tissue is produced in the basal stem of plants. This gall tumor is known as “water bamboo”, 'Kal-peh-soon' or 'Jiaobai'. The red shell water bamboo cultivar, a single-season plant, and green shell cultivar, a multi-season plant, are two main cultivars in Taiwan. However, with LED technology, the green shell cultivar is now harvested year-round. The major difference in the two cultivars is that the red shell cultivar grows with red spots on the inner layer of the leaf sheath and the other lacks these spots.

The cultivar variation is caused by the different characteristics of $U$. esculenta strains (Hung et al. 2001). Because U. esculenta invades host plants, its hyphae can be observed in the rhizome and basal stem of its host plant, including nodes, buds and shoots, which have been explored thoroughly by fluorescence microscopy (Jose et al. 2016). Meanwhile, auxin and cytokinin are accumulated after $U$. esculenta infection, followed by the induction of galls on the host plant.

The concentration of auxin shows a gradient variation in different stages of gall tumor (Chan and Thrower 1980; Chung and Tzeng 2004; Wang et al. 2017). During hyphae invasion, both intercellular and intracellular processes exist. With intercellular invasion, hyphae penetrate the plant cell and digest its interior contents. Several hyphae then gather in this space, followed by the production of teliospores from the ends of the hyphae (Zhang et al. 2012).

$U$. esculenta is a smut fungi belonging to the Basidiomycota. It has several common characteristics with other smut fungi, such as dimorphism of cell morphology, production of powder-like teliospores and invading the host plant as a sexual hypha (Martinez-Espinoza 1993; Kües et al. 2011; Ye et al. 2017). On the 
78 basis of the origin of gall characteristics, $U$. esculenta strains are designated as

79 teliospore (T) and mycelia-teliospore (M-T) strains. 'Baishin', 'Huashin' and 'Heishin'

80 are three types of galls found in Taiwan. Heishin usually produces the $\mathrm{T}$ strain,

81 producing abundant teliospore sori in the early gall formation stage, whereas Huashin

82 or Baishin produces the M-T strain, with few or no teliospores produced in the later

83 gall formation stage (Yang and Leu 1978; Zhang et al. 2017). Baishin has high

84 economical value as compared with Huashin. However, Heishin is discarded once

85 found in the field. Therefore, U. esculenta is forced to maintain in the mycelial state

86 and fails to complete sexual reproduction inside the vegetatively propagated crop host.

87 U. esculenta lacks several essential virulence factors and has had relatively slow

88 evolution under many years of artificial selection (Ye et al. 2017). The genome of the

89 diploid mycelium in U. esculenta was sequenced and analyzed.

90 The mating system in several fungi has been linked to the infection; examples

91 are Ustilago maydis (Bakkeren et al. 2008) and Cryptococcus neoformans (Nielsen

92 and Heitman 2007). In the broad study of fungus, the determinant genes are conserved

93 and have been reviewed: mating factor ( $m f a$ ), pheromone receptor (pra), and

94 heterodimeric homeodomain transcription factors (HD1 and HD2) ( $b E$ and $b W$ genes

95 in $U$. maydis) (Brefort et al. 2009). When two opposite mating-type cells meet, one

96 pheromone is recognized by another pheromone receptor. $M f a$ encodes a precursor

97 pheromone peptide, which is sensed and received by a pheromone receptor. The Pra

98 protein then triggers the MAPK module and Prf1 protein to activate the expression of

99 the bE/bW heterodimer complex (encoded by $b E$ and $b W$ genes). The subsequent

100 pathogenic progress begins, including development of the conjugation tube and

101 penetration. (Anderson et al. 1999; Brefort et al. 2009; Kües et al. 2011)

102 Sexual behavior in the fungi is known as homothallism or heterothallism.

103 Heterothallism is further classified as bipolar and tetrapolar based on the absence of 
104 genetic linkage of $\mathrm{a}$ and $\mathrm{b}$ gene regions. A gene region mainly includes pra and $m f a$ 105 genes, whereas $\mathrm{b}$ gene region contains $b E$ and $b W$ genes. Several smut fungi 106 identified by mating type include $U$. maydis ( $2 \mathrm{a}$ and $25 \mathrm{~b}$ gene complex) and 107 Sporisorium reilianum (3 a and 5 b gene complex), which are tetrapolar, and Ustilago 108 hordei, which is bipolar (Stakman and Christensen 1927; Schirawski et al. 2005; Kües 109 et al. 2011). U. hordei carries the largest mating-type loci in smut fungi: MAT-1 and 110 MAT-2, which are 500 and $430 \mathrm{~kb}$, respectively (Bakkeren and Kronstad 1994; Lee et 111 al. 1999). As well, 50\% of long terminal repeats and transposable elements appear on 112 MAT-1 (Horns et al. 2012).

113 The origin of the mating system is controversial. Genome comparison of these 114 regions inferred that $U$. maydis and $U$. hordei both evolved from S. reilianum, so the evolution of the mating system was from tetrapolar to bipolar (Bakkeren et al. 2006; Laurie et al. 2012). The U. esculenta mating system is considered tetrapolar (Yang and Leu 1978) and carries three gene complexes and three b gene complexes (Ye et al. 2017). However, we lack solid evidence for this.

Every year, farmers face huge production loss because of the formation of 120 teliospores in water bamboo for unknown reasons. Without understanding the process 121 of infection, solving this problem is difficult. This study examined the mating type 122 locus of $U$. esculenta and three other smut fungi. To further understand the $U$. 123 esculenta mating process and its possible application for reducing agricultural 124 production loss, we aimed to reveal the complete mating type locus of $U$. esculenta 125 and its system.

\section{MATERIALS AND METHODS}

128 Isolation and preservation of $\boldsymbol{U}$. esculenta 
129 Two main cultivars, green shell and red shell, of Zizania latifolia-infected samples

130 were collected from the commercial fields and an agricultural research institute in

131 Taiwan. The red shell cultivar is mainly distributed in northern Taiwan, and the green

132 shell cultivar is predominantly cultivated in central Taiwan. U. esculenta was isolated

133 from the galls of infected plants by micromanipulation or tissue isolation.

134 Micromanipulation was used to isolate strains from galls with teliospore sori. In brief,

135 teliospores were collected from infected tissues and suspended in sterile water. Spores

136 were spread onto potato dextrose agar (PDA) containing $50 \mu \mathrm{g} / \mathrm{ml}$ chloramphenicol to

137 induce germination at $28^{\circ}$. About 18 to $20 \mathrm{hr}$ post-incubation, haploid meiotic

138 progeny were picked by micromanipulator (ECLIPSE 50i, Nikon) when most

139 promycelia contained four sporidia. Tissue isolation was used to isolate strains from

140 galls lacking black sori. Leaf sheaths were first removed and intact galls were

141 collected and cut open under laminar flow. Ten pieces of internal tissue were

142 aseptically excised, placed on PDA medium containing $50 \mu \mathrm{g} / \mathrm{ml}$ chloramphenicol,

143 and incubated at $28^{\circ}$ for 1 to 2 weeks. Sporidial colony produced from the sections

144 were then re-suspended, diluted and spread on PDA medium. Finally, haploid

145 sporidial strain was obtained from a single colony. Strains were preserved by

146 culturing strains at $28^{\circ}$ in potato dextrose broth (PDB) plus $1 \%$ sorbose for $72 \mathrm{hr}$.

147 Culture was then mixed with an equal volume of cryoprotective liquid (20\% glycerol,

$14810 \%$ lactose), kept at $-20^{\circ}$ for 30 min and then stored at $-80^{\circ}$.

\section{Nuclear and septal staining}

150 Nuclear and septal staining were performed by using 4', 6-diamidino-2-phenylindole

151 (DAPI; Sigma) and calcofluor white (CFW; fluorescent brightener 28, Sigma). $U$.

152 esculenta cells were first fixed in fixation buffer $(3.7 \%$ formaldehyde, $0.1 \mathrm{M}$

153 phosphate buffer, $0.2 \%$ Triton) for $30 \mathrm{~min}$, then rinsed with sterile distilled water.

154 Samples were stained with CFW $(10 \mu \mathrm{g} / \mathrm{ml})$ for 5 min and washed with distilled water, 
155 then stained with DAPI $(0.8 \mu \mathrm{g} / \mathrm{ml})$ for $30 \mathrm{~min}$ and finally de-stained with distilled

156 water. Stained samples were examined by fluorescent microscopy (Olympus BX41)

157 with a filter set (Olympus, U-MWU2 BP330 385).

158 Mating assay

159 Haploid U. esculenta strains subjected to mating assay were cultured on PDA medium 160 at $28^{\circ}$ for 3 days. Haploid yeast strains were individually re-suspended in sterile water 161 and mixed in pairs with an equal amount. Then, a 5- $\mu$ l cell mixture was spotted onto 162 PDA medium containing $1 \%$ charcoal. After 10 to 14 days, if two tested strains were 163 compatible for mating, mating hyphae developed around the edge of the colony. 164 Alternatively, for mating assay conducted on GMM medium (Shimizu and Keller 165 2001), mating filaments were formed and visible within 3 to 5 days. Photos of mating 166 colony were taken by camera (Coolpix P300, Nikon).

\section{DNA extraction}

168 To extract U. esculenta genomic DNA, strains were freshly grown in PDB with 169 agitation at $28^{\circ}$ for $60 \mathrm{hr}$. Cells were harvested by centrifugation and lyophilized. Cell 170 materials of about $0.1 \mathrm{~g}$ were re-suspended in $500 \mu \mathrm{l}$ of $65^{\circ}$ pre-warmed CTAB buffer 171 (2\% CTAB, $1.4 \mathrm{M} \mathrm{NaCl}, 20 \mathrm{mM}$ EDTA, $100 \mathrm{mM}$ Tris $\mathrm{pH}$ 8, 2\% PVP-40) and $3 \mu \mathrm{l}$ 172 mercaptoethanol was added. Samples were incubated at $65^{\circ}$ for $30 \mathrm{~min}$ and mixed 173 every $10 \mathrm{~min}$ by inverting the tubes. After $30 \mathrm{~min}, 500 \mu \mathrm{l}$ phenol/chloroform $(1: 1$ 174 volume ratio) was added. Samples were gently mixed and then spun at $15600 \mathrm{~g}$ for 15 175 min. After centrifugation, the upper aqueous phase was transferred to a new tube and 176 an equal volume of chloroform was added. Samples were gently mixed and spun at $17715600 \mathrm{~g}$ for $5 \mathrm{~min}$. The upper aqueous phase was transferred to a new tube, and 0.7 178 times the volume of isopropanol was added. Samples were inverted for 10 times, kept 179 on ice for $10 \mathrm{~min}$ and underwent centrifugation at $15600 \mathrm{~g}$ for $5 \mathrm{~min}$. Supernatants 180 were discarded, and pellets were washed by adding $500 \mu \mathrm{l}$ of $75 \%$ ethanol. Samples 
181

182

183

184

185

186

187

188

189

190

191

192

193

194

195

196

197

198

199

200

201

202

203

204

205

were spun at $15600 \mathrm{~g}$ for $5 \mathrm{~min}$ and supernatants were carefully removed. DNA pellets were air-dried, and $100 \mu \mathrm{l}$ of sterile distilled water was added to re-suspend the DNA. DNA concentration was measured by spectrophotometry (NanoDrop 1000, Thermo Fisher Scientific, USA) and DNA samples were stored at $-20^{\circ}$.

For PCR screening, DNA template was prepared by the fast preparation of fungal DNA (FPFD) method (Liu et al. 2011). First, a small quantity of yeast cells was suspended in $100 \mu \mathrm{l}$ extraction buffer $\left(15 \mathrm{mM} \mathrm{Na}_{2} \mathrm{CO}_{3}, 35 \mathrm{mM} \mathrm{NaHCO} 3,2 \%\right.$ PVP40, 0.2\% BSA, $0.05 \%$ Tween20), then incubated at $95^{\circ}$ for $15 \mathrm{~min}$. The tube was immediately kept on ice and spun down by centrifugation. Then, $3 \mu l$ supernatant was used as template DNA for PCR reactions.

\section{Identification of $U$. esculenta mating type-related genes by PCR}

To identify the mating type genes of $U$. esculenta, several PCR approaches were used.

Sequences for evolutionally conserved genes related to mating type locus and flanking regions, including $b E$, pra, lbal, panC, cldl and Natl, from related smut fungi were aligned. Conserved regions were identified, and specific or degenerate PCR primers were designed for PCR amplification as described (Albert and Schenck 1996). PCR fragments with expected sizes were purified and underwent TA cloning (pGEM-T Easy, Promega). Transformants were screened and verified by sequencing. To amplify the complete A/B mating type locus, long-range PCR was conducted with primers designed on the flanking genes of the mating type locus. PCR conditions followed that suggested in the product manual (Q5 Hot Start High-Fidelity DNA Polymerase, New England Biolabs; TaKaRa LA Taq DNA Polymerase, TaKaRa Bio). Six $U$. esculenta isolates, 12JK1RB1-A1 (a1b1), 12JK1RB1-A2 (a3b3), 12SB1RB1-B4 (a2b2), 13PJ1GB1-D3 (a1b1), 13PJ1GB1-D4 (a2b2), and 13PJ3GB1-E1 (a3b3), were selected to determine the sequences of mating type locus.

\section{Screening of $U$. esculenta mating type by multiplex PCR}


207 Three sets of idiomorph specific primers for mating type A and B gene clusters were 208 designed to screen the mating type of $U$. esculenta isolates. Multiplex PCR reaction 209 was performed as follows: denaturation at $94^{\circ}$ for $3 \mathrm{~min}, 35$ cycles of denaturation at $21094^{\circ}$ for $45 \mathrm{sec}$, annealing at $55^{\circ}$ for $30 \mathrm{sec}$, and extension at $72^{\circ}$ for $25 \mathrm{sec}$, and final 211 extension at $72^{\circ}$ for $7 \mathrm{~min}$.

\section{Illumina sequencing of $\boldsymbol{U}$. esculenta genome}

213 To prepare high-quality genomic DNA for next-generation sequencing, a modified 214 CTAB method was used (Winnepenninckx et al. 1993). Briefly, U. esculenta strains 215 were first grown in PDB for $60 \mathrm{hr}$ and cells were collected by centrifugation and 216 lyophilized, then suspended in $800 \mu \mathrm{l}$ of $60^{\circ}$ pre-warmed CTAB buffer $(2 \% \mathrm{CTAB}$, $2171.4 \mathrm{M} \mathrm{NaCl}, 20 \mathrm{mM}$ EDTA, $100 \mathrm{mM}$ pH 8 Tris, 2\% PVP-40) plus $0.2 \%$ 218 mercaptoethanol and $0.1 \mathrm{mg} / \mathrm{ml}$ proteinase K. Samples were incubated at $60^{\circ}$ for $1 \mathrm{hr}$ 219 and gently inverted every $20 \mathrm{~min}$. After incubation, $800 \mu \mathrm{l}$ chloroform/isoamyl 220 alcohol (24:1) was added and gently mixed for $2 \mathrm{~min}$. Samples were then centrifuged 221 at $14000 \mathrm{~g}$ for $10 \mathrm{~min}$ at $4^{\circ}$. The upper aqueous phase was transferred to a new tube, 222 and $1 \mu \mathrm{l}$ RNase $(100 \mu \mathrm{g} / \mu \mathrm{l})$ was added and kept at $37^{\circ}$ for $90 \mathrm{~min}$, then $600 \mu \mathrm{l}$ 223 isopropanol was added, mixed gently, and samples were kept at room temperature 224 overnight to allow DNA precipitation. The next day, samples were centrifuged at $22514000 \mathrm{~g}$ for $15 \mathrm{~min}$ at $4^{\circ}$. Supernatants were discarded and pellets were washed by 226 adding $800 \mu \mathrm{l}$ of $75 \%$ ethanol. Samples were spun for $5 \mathrm{~min}$ at $15600 \mathrm{~g}$, and 227 supernatants were removed completely and pellets were air-dried. Finally, $100 \mu 1$ 228 sterile distilled water was added to re-suspend DNA pellet. DNA samples were 229 quantified by Qubit (Invitrogen) and the concentration was adjusted to $10 \mathrm{ng} / \mu \mathrm{l}$. For 230 DNA shearing, Covaris S2 (Covaris, MA, USA) was used to break DNA into 200-bp 231 fragments; fragments 200 to $700 \mathrm{bp}$ were selected by using Ampure XP beads 232 (Beckman Coulter Genomics, CA, USA). 
234 size-selected fragments were repaired, and poly A nucleotides were added to 3' ends.

235 Poly T complemented specific adaptors were linked to both ends of fragments and 10 236 cycles of PCR amplification were conducted. The distribution of fragment size was 237 confirmed by BioAnalyzer before next-generation sequencing (Agilent Technologies, 238 CA, USA). Pair-ended sequencing with 250-bp reads was conducted with Illumina 239 MiSeq (Illumina Inc., CA, USA) at the NGS Core (Center for Systems Biology, 240 National Taiwan University).

241 The cluster density of sequencing was $1105 \mathrm{~K} / \mathrm{mm}^{2}$ and size of 12JK1RB1-A1 242 and 12JK1RB1-A2 was 5.5 and $4.6 \mathrm{~Gb}$. Three assembly programs were used: CLC 243 bio, SOAPdenovo (Short Oligonucleotide Analysis Package) and velvet. Performance 244 was assessed by read mapping rate and number of orthologous proteins between $U$. esculenta and $U$. maydis. The assembled results with CLC bio were better than with other methods and were used for gene annotation. The average base coverages were $230 \mathrm{X}$ and $194 \mathrm{X}$ for 12JK1RB1-A1 and 12JK1RB1-A2.

\section{Long-read PacBio sequencing}

249 The method was modified from the Gentra kit DNA extraction procedure. Briefly, 250 3-day-old $U$. esculenta strains were first incubated in $5 \mathrm{ml} \mathrm{PDB}$ for $24 \mathrm{hr}$ and then 251 transferred to a 125-ml flask and grown for another $34 \mathrm{hr}$ (no longer than $36 \mathrm{hr}$ ). Cells 252 were then counted to approximate $2 \times 10^{8}$ cells. First, samples were suspended in $300 \mu 1$ 253 cell suspension solution and $60 \mathrm{mg}$ VinoTaste (Novozymes), followed by reaction at $25437^{\circ}$ for $1 \mathrm{hr}$. After that, $300 \mu \mathrm{l}$ cell lysis solution plus $1 \%$ SDS was added for 255 incubation at $50^{\circ}$ for another $30 \mathrm{~min}$. Then, $100 \mu$ protein precipitation solution was 256 added, followed by vigorously vortexing for $20 \mathrm{sec}$, then centrifugation for $3 \mathrm{~min}$ at $25716,000 \mathrm{~g}$, then DNA was pelleted by inverting the tubes 50 times with the addition of $258300 \mu \mathrm{l}$ isopropanol. Pure DNA was acquired by washing with $70 \%$ Ethanol, 5 to 10 
259 min air drying and re-suspended with $100 \mu$ DNA hydration solution. Finally, RNA 260 was removed with $1.5 \mu \mathrm{l}$ RNase A solution and incubated at $37^{\circ}$ for $60 \mathrm{~min}$ for 261 enzyme reaction, then transferred to $65^{\circ}$ water bath for 60 -min incubation.

262 Genomic DNA was sheared by using a Covaris g-TUBE followed by purification 263 via binding to pre-washed AMPure PB beads (Part no. PB100-265-900). After 264 end-repair, the blunt adapters were ligated and underwent exonuclease incubation to 265 remove all un-ligated adapters and DNA. The final "SMRT bells" were annealed with 266 primers and bound to the proprietary polymerase by using the PacBio 267 DNA/Polymerase Binding Kit P6 v2 (Part no. PB100-372-700) to form the "Binding 268 Complex". After dilution, the library was loaded onto the instrument with the DNA 269 Sequencing Kit 4.0 v2 (Part no. PB100-612-400) and 4 SMRT Cells 8Pac for 270 sequencing. A primary filtering analysis was performed with the RS instrument, and 271 the secondary analysis involved using the SMRT analysis pipeline v2.3.0.

\section{Bioinformatics analysis}

273 Protein coding genes of $U$. esculenta were predicted by using GeneMark-ES 274 (Borodovsky and Lomsadze 2011) to scan the assembled contigs, then the predicted 275 genes were annotated in a similarity-based manner. NCBI-BLASTP (Altschul et al. 276 1990) was used to search for homologous genes in UniRef clusters (Suzek et al. 2015).

277 When finding significantly similar hits to a predicted gene (i.e., with e-value $<10^{-4}$, low 278 complexity filtering by using SEG program), the annotation information was retrieved 279 from the best hit; otherwise, HMMer and Pfam HMM models were used to predict the 280 protein domains in the encoded amino-acid sequences of the genes remaining 281 unannotated in the similarity-based annotation step (Durbin et al. 1998; Finn et al. 282 2016).

283 Repeat and transposable elements were predicted by using RepeatModeler 1.0.8 284 plus the RMBlast search tool (Smit and Hubley; Smit et al.) and TransposonPSI (Haas). 
285 Part of the genome comparison analysis was carried out by using MUMmer 3.23 (Kurtz 286 et al. 2004) and diagrammed by using Easyfig 2.2 (Sullivan et al. 2011). Comparative 287 analysis of the UE genome with 10 other fully-sequenced fungal genomes, including 288 Aspergillus nidulans, Cryptococcus neoformans, Magnaporthe oryzae, Neurospora crassa, Phytophthora infestans, Puccinia graminis, Saccharomyces cerevisiae, Sporisorium reilianum, Ustilago maydis and Ustilago hordei, involved using the Ensembl Compara pipelines, with inter-species syntenic regions and phylogenetic trees of all protein-coding genes inferred by using the Lastz-net pipeline (Kent et al. 2003) and the GeneTrees pipeline (Vilella et al. 2009), respectively. All the results of genome annotation and comparative analysis were integrated into a locally maintained Ensembl genome database and browser system for further data mining and visualization.

\section{Inoculation experiment}

297 For inoculation experiments, U. esculenta isolates were first cultured on PDA medium at $28^{\circ}$ for 5 to 7 days. Uninfected Z. latifolia plants collected from the field were used for inoculation. Collected plants were initially washed clean with tap water. Unwanted leaves, leaf sheaths, and roots were removed, and 15 to $20 \mathrm{~cm}$ long of basal stems containing young buds were saved. Basal stem tissues were further washed with distilled water, kept in a plastic box containing perlite and distilled water, then grown

303 in a controlled growth chamber with the conditions of $24^{\circ}, 75 \%$ relative humidity, 8 $304 \mathrm{hr}$ daylight with light intensity $75 \mu \mathrm{mol} \mathrm{s} \mathrm{m}^{-1}$ for 3 to 5 days to maintain viability. 305 After incubation, the buds showing vigorous viability were selected for inoculation. Outer layers of leaf sheath surrounding the buds were removed and two tiny holes

307 pierced into one bud tissue were created by using an insect-pinning pin. Yeast cells of 308 compatible $U$. esculenta isolates were mixed in equal amount and applied to wounded 309 sites on buds. The inoculated samples were placed back into a perlite box and tightly 310 covered with a plastic bag to retain humidity. The plastic bag was dislodged 3 days 
311 later, and inoculated samples were maintained in a controlled growth chamber at $24^{\circ}$,

$31275 \%$ relative humidity, 8 -hr daylight with light intensity $75 \mu \mathrm{mol} \mathrm{s}{ }^{-1} \mathrm{~m}^{-2}$. After 2

313 weeks, surviving buds were excised, transferred to soil pots and grown in a

314 greenhouse. Evaluation of successful inoculation rate was conducted 4 to 6 weeks

315 post-inoculation by examining whether swelling of the basal stem occurred.

316 Data availability

317 All data necessary for confirming the conclusion of the article are present in the 318 article, figures and tables. Sequencing data used in this research was deposited in the 319 NCBI (data will be submitted to NCBI later). Figure S1 presents the reads coverage of 320 genome of MAT-1. Figure S2 illustrates the syntenic region of MAT loci between $U$. 321 esculenta and $U$. hordei. Table S1 and S2 are U. esculenta strains isolated from the 322 fields. Table S3 presents the primer sets used in this study.

RESULTS

\section{Field plant collection and isolation of $\boldsymbol{U}$. esculenta}

326 Two field cultivars, red and green shells, were collected from northern Taiwan 327 (Jinshin) and central Taiwan (Puli), respectively (Figure 1A). According to the 328 presence of teliospores, these collections were classified into three groups: Baishin, 329 Huashin and Heishin. Baishin refers to a snowy white gall without teliospores (Figure 330 1B, C). Heishin is known by a huge number of teliospores scattered inside the gall, 331 whereas Huashin has fewer teliospores. Furthermore, Heishin is smaller and grows 332 faster than Huashin during the harvest time (Figure 1D).

333 U. esculenta strains were isolated by micromanipulation or directly from plant 334 tissue. With the former method, 59 strains were separated from Heishin tissue, 335 including 44 strains from 11 sets of four meiotic progenies and 15 strains from 7 
336 incomplete sets. Strains from Baishin and Huashin were directly isolated from plant

337 tissue: 9 from Baishin tissue and 77 from Huashin tissue (Table S1, S2, S3).

\section{Life cycle of $\boldsymbol{U}$. esculenta}

339 Most smut fungi share a similar life cycle pattern; however, U. esculenta is slightly 340 different from others because of the artificial vegetative propagation. For more than 341100 years, farmers have tried to avoid the development of teliospores in the paddy 342 field. Thus, most U. esculenta strains in the wild remain in the hyphae state. Under 343 natural circumstances, as for other smut fungi, U. esculenta infects host plants as 344 filaments and produces tumor-like tissue and teliospores (Figure 2A). Teliospores 345 germinated and produced 2 septa, then evolved to 5 or 6 septa in promycelium while 4 346 meiotic yeast-like sporidia were produced. The fourth sporidia usually budded from 347 the teliospore directly. Likewise, sporidia, which were unicellular or multicellular, 348 also performed an in vitro asexual cycle. When opposite sporidia were conjugated and 349 formed sexual filaments, we found three characteristics in the mating filaments by 350 using DAPI and CFW stains. In young filaments, the front end region included living 351 cells and dead cells, which were present as empty-cytoplasm sections. In the late stage, 352 several dikaryotic cells appeared at the tip region, and the monokaryotic yeast cells 353 budded from the growth tip and the edge of some septa (Figure 2E-2H).

\section{$354 \quad$ U. esculenta features heterothallism}

355 U. esculenta is known as a heterothallic fungi. To reveal the mating type system, we used mating assay by inter/intra-mating assay of 6 sets of teliospore-isolated strains,

357 including 3 sets from green shell cultivars (13PJ1GB1, 13PJ3GB1, 13PS2GB1) and 3

358 sets from red shell cultivars (2 from 12SB1RB1 and 1 from 12JK1RB1). For the 359 intra-mating results, 4 of 6 crossings showed furry colonies (Figure 3A), so two 360 different mating types were present in the 4 meiotic progenies. For the inter-mating 361 results, both 8 and 12 compatible crossings were observed among the 16 crossings 
362 (Figure 3B, C). The former result featured two different mating type loci in 8 strains,

363 and the later result more than 2 mating types (Table 1).

\section{U. esculenta has 3 idiomorphs of mating type}

365 We used the PCR primer sets for U. scitaminea bE gene (Albert and Schenck 1996), 366 then designed degenerate PCR to amplify the flanking genes of A and B gene 367 complexes. The flanking genes $c 1 d 1$, natl, lbal and panC were amplified. To obtain 368 the complete sequence of mating type, whole-genome sequencing of 12JK1RB1-A1 369 (MAT-1) and 12JK1RB1-A2 (MAT-3) involved using Illumina Hi-seq.

370 Sequences of the non-coding region between $b E$ and $b W$ genes and the partial 371 sequence of $b W$ gene were highly diverse. By comparing this region among 23 372 field-collected strains, we found 3 different lengths of amplicons: 2,028, 2,130 and $3732,141 \mathrm{bp}$, which were partial sequences of MAT-1, MAT-2 and MAT-3. The primer set used was wc1529 and wc1531 (Table S4).

The full sequences of A and B gene complexes were obtained by PCR cloning 376 or whole-genome sequencing (primer sets: Table S4). The length of three A gene 377 complexes was $6,455,8,129$ and 7,156 bp, respectively, with B gene complexes 7,433 , 3787,325 and 14,165 bp respectively.

379 Differences in MAT locus within $U$. esculenta strains and other species

380 A gene complex in $U$. esculenta includes several genes: pheromone receptor ( $p r a)$, 381 two pheromones ( $m f a$ ) and lga/rga and is flanked by a left-border protein $(l b a)$ and 382 right-border protein ( $r b a)$ (Figure 4). The B gene complex, which was flanked by 383 proposed nuclear regulator $(c l d l)$ and N-terminal acetyltransferase (Natl) genes, 384 mainly contained $\mathrm{b}$ West $(b W)$ and $\mathrm{b}$ East $(b E)$ genes (Figure 5). Three $\mathrm{a} / \mathrm{b}$ gene 385 complexes share high synteny with other smut fungi, including U. maydis, U. hordei, 386 and S. reilianum. 
The pheromone-receptor $(\mathrm{P} / \mathrm{R})$ system of $U$. esculenta involved three Pra 388 proteins and six Mfa proteins. Phylogenetic trees (Figure 6B, C) revealed that both 389 Mfa and Pra proteins are divided into 3 clades. The similarity of Mfa and Pra proteins 390 in each clade was up to $90 \%(76-90 \%)$ and $86 \%$ (76-86\%). However, the similarity of 391 U. maydis Mfa2 to other proteins in the same clade was merely $56 \%$ to $65 \%$ (Figure 392 6B). Also, mfa1.3 and $m f a 2.3$ showed a slight difference at the N-terminus but might 393 be identical after processing (Figure 6A).

394 Two mitochondria inheritance-related genes, rga2 and rga3, encoding a 395 mitochondrial targeting signal (MTS), were detected among U. esculenta populations, 396 and were located on the a2 and a3 gene complex, respectively (Figure 4). The protein 397 similarity of the $2 \mathrm{Rga}$ proteins was $49 \%$, and that of homologous genes in another 398 smut fungi Ustanciosporium gigantosporum was 90\%. Rga2 of U. esculenta was 399 much closer to those of other species, including Sporisorium walker, Macalpinomyces 400 eriachnes, $U$. maydis and $S$. reilianum, than its own Rga3 protein. As well, rga3 401 protein of $U$. esculenta showed $66 \%$ similarity to U. xerochloae protein and $52 \%$ 402 similarity to U. gigantosporum protein. The $2 \mathrm{rga}$ genes might have evolved from 2 403 different ancestors (Figure 7. However, in another Chinese isolate, MMT, rga3 is 404 missing and is replaced by a transposon-related region (Ye et al. 2017). This finding 405 indicates the high activation of transposable elements in the U. esculenta population. 406 Another genetic variation event occurred on the MAT locus. Fot1 family DNA 407 transposon was inserted in the $\mathrm{b}$ gene complex. This characteristic was reported in 408 other isolates and was similar to S. reilianum SRZ2 and S. scitamineum SscI8 but with 409 the opposite site of the $\mathrm{b}$ gene complex (Figure 5). Transposons in U. esculenta b1 410 and b2 gene complexes were both 2256 bp and showed $99 \%$ similarity. However, the 411 transposon on the b3 gene complex was an exception - $9087 \mathrm{bp}$ - and inserted by 412 several short repeats and sequence. The repeats range from 30 to 69 bp (Figure 5). 
Mating type system of $U$. esculenta is bipolar

414 Complete MAT-1 and MAT-2 loci were retrieved from 12JK1RB1-A1 (MAT-1) and 415 UE_mtsf (MAT-2) and underwent single molecule real time (SMRT) sequencing. The 416 mating type locus (MAT) was identified by using previous identified a and $\mathrm{b}$ gene 417 complexes. The MAT-1 region was covered by 81.15 sequencing reads, on average, 418 which indicated high confidence of its correctness (Figure S1). The sequences within 419 MAT-1 were variable. MAT-1 was 555,862 bp and included 115 genes (Table S5) and 420 more than 20 transposable elements predicted by TransposonPSI. About $44.28 \%$ 421 featured repeats, with greater proportion than in the non-MAT region $(33.13 \%)$.

422 Sequence-region comparison revealed similarity of 2 sequences. U. esculenta 423 MAT-1 and MAT-2 sequences showed $66.1 \%$ identify by pairwise global alignment 424 (blastn). However, about 61.8\% (343,440/555,862 bp) of the MAT-1 sequence showed synteny to MAT-2 and more than $95 \%$ identity to each other. However, most of the rest of the MAT-1 region (39.2\%) was an intergenic region and occupied by repeats or 427 transposable elements. Some repeats on MAT-1 were similar ( $80 \%$ to $94 \%$ identity) to 428 those of MAT-2 and spotted on several locations. These sequence phenomena were 429 similar to those for U. hordei MAT-1.

430 Both U. esculenta and U. hordei mating systems were bipolar but with extremely 431 different mating type locus (MAT). Only a partial sequence of U. esculenta MAT-1 432 was similar to $U$. hordei chromosome 2. In contrast, U. esculenta shared more 433 consensus regions of MAT-1 and sex chromosome with U. maydis (Figure 8) and had 434 a continuous similar sequence with S. reilianum (Figure 9). This observation 435 suggested the high relatedness among U. esculenta, U. maydis and S. reilianum 436 during species evolution. Both U. esculenta and U. hordei underwent a certain genetic 437 event, probably similar, for repeats to have a high portion of mating type locus and to 
438 prevent MAT loci recombination, so the mating systems are bipolar rather than 439 tetrapolar.

\section{Recombination of mating type locus was suppressed in sexual progenies}

$441 U$. maydis was tetrapolar because the mating type sequence on its four sporidia 442 (progenies) underwent recombination event during meiosis (Kües et al. 2011). To 443 discover whether such phenomena occurred on the MAT locus of U. esculenta, we 444 gathered teliospores from 2 inoculated plants and incubated their sexual progenies to 445 analyze their mating types. The mating analysis involved using complex PCR (Figure $44610)$.

447 The first group including 466 strains was the offspring of 13PS2GB1-A3 448 (MAT-3) and 13PS2GB1-A4 (MAT-2). By using multiplex RCR, we found only 2 449 mating types, MAT-2 (a2/b2) and MAT-3 (a3/b3), which were the same type as their 450 parental strains. Similar results were found in another group [13PJ3GB1-A2 (MAT-1) $451 \times$ 13PJ3GB1-A4 (MAT-3)] (Table 2). Because no recombination occurred on the 452 mating type locus during meiosis, the mating system of U. esculenta was bipolar.

\section{DISCUSSION}

455 Water bamboo cultivars have been used for long-term artificial selection. However, 456 we do not thoroughly understand the mating system and the impact on gall formation. 457 By studying recombination on the mating type locus and by whole-genome 458 sequencing, we revealed that the mating system of $U$. esculenta is bipolar and has 459 three different mating type loci: MAT-1 (555,863 bp), MAT-2 (508,427 bp) and

460 MAT-3. The characteristics of MAT-1 are similar to U. hordei MAT-1, including 461 accumulation of insertion elements and different sizes of idiomorphs. Most of MAT-1 462 is highly syntenic to sex chromosomes of U. maydis and S. reilianum, which indicates 
463 the occurrence of a recombination event. Several transposable elements (TEs) occur

464 within the region of mating-related genes (a/b gene complexes): one isolate carries 465 rga, but the corresponding region on another isolate is replaced by TEs. The other 466 example is the appearance of fot 1 family transposons on each B-gene complex, which 467 are located at different positions, as compared with S. reilianum.

\section{$468 \quad$ U. esculenta strain study in Taiwan}

469 In the 145 Taiwanese isolates, three mating types are distributed randomly around 470 Taiwan and can invade both green and red cultivars (Table 3). These observations 471 suggest no distributional differences of mating type in Taiwan.

472 All collected isolates are from Heishin (T strain), Haushin (unknown strain) or 473 Baishin (MT strain) (Yang and Leu 1978). T strains produce teliospores, but M-T 474 strains do not. With our observations and literature studies, Baishin is prone to 475 transform to Heishin plants under poor weather or in older plants. As compared with 476 Heishin, Baishin is favored by the farmer because of its financial value in the market. 477 However, in this study, we used Heishin isolates for several reasons. Heishin isolates 478 have a complete life cycle and produce teliospores. Its haploid strains are easier to 479 isolate and to use for in vitro studies than are Baishin isolates. Furthermore, because it 480 has a natural instinct for producing sexual progeny to finish its life cycle, the M-T 481 strain (Baishin) may be a mutant of the T strain (Heishin).

482 Two teliospore-related genes, $h d a 1$ and rum 1, are slightly different between mtsf 483 and JSKK29

484 Teliospores form after undergoing a series of filament morphological changes: 485 branching, collapsing, swelling, fragmentation, and teliospore formation (Banuett and 486 Herskowitz 1996). During the procedure, several proteins, Fuz1, Hgl1, (histone 487 deacetylase) Hda1 and Rum1 (homology of human retinoblastoma binding protein 2), 488 are involved in teliospore formation. Gene mutants would cause the absence of 
teliospores (Chew et al. 2008). In our morphological and staining studies of JSKK29,

490 we observed only hyphae branching and partial empty septa. Protein sequence 491 alignment revealed a difference of three peptides between mtsf and JSKK29 in hda1 492 and rum1, which showed $99.49 \%$ and $99.87 \%$ identity, respectively. Clarifying the 493 cause of teliospores in the water bamboo needs further study.

\section{Mating type-related genes reveal the evolutionary information of $\boldsymbol{U}$. esculenta}

$495 U$. esculenta has 3 idiomorphs, MAT-1, MAT-2 and MAT-3. Its gene structure is 496 similar to that of $S$. reilianum, which harbors 2 pheromones on each A mating type 497 locus. We examined all pheromones of U. esculenta and related smut fungi (Figure 5). 498 Two pheromones received by the same receptor, such as Mfa3.1 and Mfa2.1 499 activating Pra1, are very similar regardless of pre- or pro-mature peptides. However, 500 pre-mature peptides of Mfa2.3 and Mfa1.3 at the N-terminal in U. esculenta differ. 501 The Mfa2.3 sequence is similar to that of S. reiliuanum Mfa1.2 and Mfa3.2, whereas 502 the Mfa1.3 sequence is much closer to that of S. reiliuanum Mfa1.3 and Mfa2.3. This 503 divergent sequencing is evidence of the evolutionary remnant between 2 groups of 504 pheromones.

$505 \quad \lg a$ and $\operatorname{rga}$ are 2 uniparental mitochondrial-related genes on the A gene complex. 506 Because mutation accumulation usually occurs in mitochondrial inheritance, 507 investigating these 2 genes may reveal clues about the original species of smut fungi 508 (Hoekstra 2000; Fedler et al. 2009). Both U. maydis and S. reilianum carry one lga 509 and $r g a$ on the a2 gene complex, whereas $U$. esculenta harbors one lga-like gene and 5102 rga genes on MAT-2 and MAT-3. The proteins Lga and Rga interfere with 511 mitochondria fusion and regulate pathogenicity in the presence or absence of $m r b 1$ 512 and dnml (Bortfeld et al. 2004; Mahlert et al. 2009; Fedler et al. 2009). Because $U$.

513 esculenta has the homologous genes of $m r b 1$ and $d n m l$ and its $\lg a$ is not complete as 514 for other smut fungi, lga might not be required in $U$. esculenta, which underwent 
515 long-term human selection. U. esculenta has 2 rga genes (rga2 and rga3) on MAT-2 516 and MAT-3. U. gigantosporum carries 2 Rga proteins as well. However, its genes 517 show high identity (90\% identity), whereas those in U. esculenta do not (49\% 518 identity). As well, rga3 in isolates from China were lost and replaced by TEs. 519 Because China has a longer cultivar history of water bamboo than Taiwan, this gene 520 variation event indicates that rga is less important than other mating-related genes.

521 Pheromone precursors of pra3 in $\boldsymbol{U}$. esculenta support that the third R/P system 522 is a variation of other two

$523 U$. esculenta has 3 pheromone precursors and a pheromone receptor $(\mathrm{P} / \mathrm{R})$ system 524 similar to S. reilianum. The third pheromone-pheromone receptor system is found 525 only in the basidiomycetes (Kües et al. 2011) and is divergent from a common 526 ancestor of other 2 systems. Our phylogenetic analysis (Figure 5B, C) revealed the 527 same result of three pheromone-pheromone receptor systems separated into 3 clades. 528 As well, the pheromone precursors of $U$. esculenta Mfa1.3 and Mfa2.3 differ at the 529 N-terminus. The former shows a closer relationship to other pheromones identified by 530 the Pra2 protein, whereas another pheromone is more similar to Mfa1.3 and Mfa2.3 in 531 S. reilianum. This observation supports that the third pheromone-pheromone receptor 532 system is a variation of the other two.

533 The mating type locus of $\boldsymbol{U}$. esculenta provides evidence to study the history of 534 MAT evolution

535 U. esculenta has a multiple-factor bipolar mating system. Its mating type locus (MAT) 536 has several characteristics described in the $U$. hordei MAT, such as accumulation of a 537 repetitive sequence that suppresses the recombination and the size variation of MAT, 538 which is caused by the insertion of TEs. The U. hordei bipolar system may be created 539 by recombination of the S. reilianum (tetrapolar) sex chromosome (Bakkeren et al. 
540 2006). However, whether the tetrapolar system evolved from the bipolar system or to

541 the bipolar system is debated (Kües et al. 2011).

543 located on the unitig_12, with length of 2,000,476 bp, with one complete telomere. In

544 terms of sequence comparison, a sequence recombination event on large fragments

545 occurred (Figure 8). About half of the $U$. esculenta unitig_12 length is syntenic to $U$.

546 maydis chromosome 1 and the other to chromosome 5. Because the event and

547 outcome are similar to that in $U$. hordei, believed to be degenerated from S. reilianum,

548 the sequence event of $U$. esculenta might be the same as $U$. hordei: both species

549 underwent sequence recombination on the sex chromosome. Sex chromosomes of $U$.

550 esculenta and $U$. hordei are very similar, except for the MAT regions. Part of the

551 sequence of $U$. esculenta MAT is similar to $U$. hordei chromosome 2, which is in

552 partial synteny to S. reilianum chromosome 20. Genes on this syntenic region in $U$.

553 hordei chromosome 2 are dense but are scattered in U. esculenta and inserted with

554 repetitive sequences. Some repetitive sequences are shared between these 2 species

555 and located on MAT and also all other sequences on the unitig_12 (Figure S2).

556 Comparative analysis revealed that $U$. esculenta underwent a sequence variation event

557 as compared with 3 other smut fungi (U. maydis, U. hordei, S. reilianum) and their

558 specialization is closely related. The discovery of the mating type of $U$. esculenta

559 provides evidence to study the evolution of the mating type system.

560 Many studies have investigated how U. esculenta and its host Z. latifolia

561 cooperate. The mating type locus is highly related to the development of filaments

562 and controls the process of infection. However, we still do not understand how $U$.

563 esculenta invades its host, how the process of tumor-like tissue formation is related to

564 infection, and whether different mating type conjugations interfere with the size of 565 tumor-like tissue. Such issues are worth of further study. 
574 Albert, H. H., and S. Schenck, 1996 PCR amplification from a homolog of the bE mating-type gene as a sensitive assay for the presence of Ustilago scitaminea DNA. Plant Dis. 80: 1189-1192.

577 Altschul, S. F., W. Gish, W. Miller, E. W. Myers, and D. J. Lipman, 1990 Basic local alignment search tool. J. Mol. Biol. 215: 403-410. al., 1999 Molecular analysis of the pheromone and pheromone receptor genes of Ustilago hordei. Gene 240: 89-97.

Bakkeren, G., and J. W. Kronstad, 1994 Linkage of mating-type loci distinguishes bipolar from tetrapolar mating in basidiomycetous smut fungi. Proc Natl Acad Sci U S A 91: 7085-7089.

585 Bakkeren, G., G. Jiang, R. L. Warren, Y. Butterfield, H. Shin et al., 2006 Mating 586 factor linkage and genome evolution in basidiomycetous pathogens of cereals. Fungal Genet. Biol. 43: 655-666.

Bakkeren, G., J. Kämper, and J. Schirawski, 2008 Sex in smut fungi: Structure, function and evolution of mating-type complexes. Fungal Genet. Biol. 45: S15S21. 
591 Banuett, F., and I. Herskowitz, 1996 Discrete developmental stages during teliospore formation in the corn smut fungus, Ustilago maydis. Development 122:.

593 Borodovsky, M., and A. Lomsadze, 2011 Eukaryotic gene prediction using 594 GeneMark.hmm-E and GeneMark-ES. Curr. Protoc. Bioinforma. Chapter 4: Unit 4.6.1-10.

Bortfeld, M., K. Auffarth, R. Kahmann, and C. W. Basse, 2004 The Ustilago maydis a2 mating-type locus genes $\lg a 2$ and rga2 compromise pathogenicity in the absence of the mitochondrial p32 family protein Mrb1. Plant Cell 16: 22332248.

600 Brefort, T., G. Doehlemann, A. Mendoza-Mendoza, S. Reissmann, A. Djamei et al., 6012009 Ustilago maydis as a pathogen. Annu. Rev. Phytopathol. 47: 423-445.

602 Chan, Y. S., and L. B. Thrower, 1980 The host-parasite relationship between Zizania 603 caduciflora Turcz. and Ustilago esculenta P. Henn. New Phytol. 85: 201-207.

604 Chew, E., Y. Aweiss, C.-Y. Lu, and F. Banuett, 2008 Fuz1, a MYND domain protein, 605 is required for cell morphogenesis in Ustilago maydis. Mycologia 100: 31-46.

606 Chung, K. R., and D. D. Tzeng, 2004 Biosynthesis of indole-3-acetic acid by the 607 gall-inducing fungus Ustilago esculenta. J. Biol. Sci. 4: 744-750.

608 Durbin, R., S. Eddy, A. Krogh, and G. Mitchison, 1998 Biological sequence analysis: 609 probabilistic models of proteins and nucleic acids. Cambridge University Press.

610 Fedler, M., K.-S. Luh, K. Stelter, F. Nieto-Jacobo, and C. W. Basse, 2009 The a2 mating-type locus genes $\operatorname{lga} 2$ and rga2 direct uniparental mitochondrial DNA (mtDNA) inheritance and constrain mtDNA recombination during sexual

614 Finn, R. D., P. Coggill, R. Y. Eberhardt, S. R. Eddy, J. Mistry et al., 2016 The Pfam 615 protein families database: towards a more sustainable future. Nucleic Acids Res. 616 44: D279-D285. 
617 Haas, B. TransposonPSI: an application of PSI-blast to mine (Retro-)transposon ORF 618 homologies.

619 Hoekstra, R. F., 2000 Evolutionary origin and consequences of uniparental 620 mitochondrial inheritance. Hum. Reprod. 15 Suppl 2: 102-11.

621 Horns, F., E. Petit, R. Yockteng, and M. E. Hood, 2012 Patterns of repeat-induced point mutation in transposable elements of basidiomycete fungi. Genome Biol. Evol. 4: 240-247.

Hung, S. F., S. L. Chang, and I. T. Chen, 2001 Using random amplified polymorphic DNA (RAPD) markers to identify the clones of coba (Zizania latifolia Turcz.) and their Ustilago esculenta P. Henn. J. Taiwan Soc. Hortic. Sci. 47: 331-340.

Jose, R. C., S. Goyari, B. Louis, S. D. Waikhom, P. J. Handique et al., 2016 Investigation on the biotrophic interaction of Ustilago esculenta on Zizania latifolia found in the Indo-Burma biodiversity hotspot. Microb. Pathog. 98: 615.

Kent, W. J., R. Baertsch, A. Hinrichs, W. Miller, and D. Haussler, 2003 Evolution's cauldron: duplication, deletion, and rearrangement in the mouse and human genomes. Proc. Natl. Acad. Sci. U. S. A. 100: 11484-9.

Kües, U., T. Y. James, and J. Heitman, 20116 Mating type in basidiomycetes: unipolar, bipolar, and tetrapolar patterns of sexuality, pp. 97-160 in Evolution of fungi and fungal-Like organisms, Springer Berlin Heidelberg, Berlin, Heidelberg.

Kurtz, S., A. Phillippy, A. L. Delcher, M. Smoot, M. Shumway et al., 2004 Versatile and open software for comparing large genomes. Genome Biol. 5: R12. 
642 silencing components and species-specific presence of transposable elements. $643 \quad$ Plant Cell 24: 1733-1745.

644 Lee, N., G. Bakkeren, K. Wong, J. E. Sherwood, and J. W. Kronstad, 1999 The 645 mating-type and pathogenicity locus of the fungus Ustilago hordei spans a 646 500-kb region. Proc. Natl. Acad. Sci. U. S. A. 96: 15026-31.

647 Liu, K. H., Y. L. Yeh, and W. C. Shen, 2011 Fast preparation of fungal DNA for PCR 648 screening. J. Microbiol. Methods 85: 170-172.

649 Mahlert, M., C. Vogler, K. Stelter, G. Hause, and C. W. Basse, 2009 The a2 650 mating-type-locus gene lga2 of Ustilago maydis interferes with mitochondrial dynamics and fusion, partially in dependence on a Dnm1-like fission component.

Martinez-Espinoza, A. D., Gerhardt, S. A., Sherwood, J. E., 1993 Morphological and mutational analysis of mating in Ustilago hordei. Exp. Mycol. 17: 200-214.

Nielsen, K., and J. Heitman, 2007 Sex and virulence of human pathogenic fungi. Adv. Genet. 57: 143-147.

657 Shimizu, K., and N. P. Keller, 2001 Genetic involvement of a cAMP-dependent protein kinase in a $\mathrm{G}$ protein signaling pathway regulating morphological and chemical transitions in Aspergillus nidulans. Genetics 157: 591-600.

661 Smit, A., R. Hubley, and P. Green RepeatMasker.

662 Stakman, E. C., and J. J. Christensen, 1927 Heterothallism in Ustilago zeae. 663 Phytopathology 17: 34-38.

664 Sullivan, M. J., N. K. Petty, and S. A. Beatson, 2011 Easyfig: a genome comparison 665 visualizer. Bioinformatics 27: 1009-1010. 
666 Suzek, B. E., Y. Wang, H. Huang, P. B. McGarvey, C. H. Wu et al., 2015 UniRef clusters: a comprehensive and scalable alternative for improving sequence similarity searches. Bioinformatics 31: 926-32.

Vilella, A. J., J. Severin, A. Ureta-Vidal, L. Heng, R. Durbin et al., 2009 EnsemblCompara GeneTrees: complete, duplication-aware phylogenetic trees in vertebrates. Genome Res. 19: 327-35.

Wang, Z. D., N. Yan, Z. H. Wang, X. H. Zhang, J. Z. Zhang et al., 2017 RNA-seq analysis provides insight into reprogramming of culm development in Zizania latifolia induced by Ustilago esculenta. Plant Mol. Biol. 95: 533-547.

Winnepenninckx, B., T. Backeljau, and R. De Wachter, 1993 Extraction of high molecular weight DNA from molluscs. Trends Genet. 9: 407.

Yang, H. C., and L. S. Leu, 1978 Formation and histopathology of galls induced by Ustilago esculenta in Zizania latifolia. Phytopathology 68: 1572-1576. analysis reveals artificial selection effects on Ustilago esculenta genome. DNA Res. 24: 635-648.

Zhang, J. Z., F. Q. Chu, D. P. Guo, K. D. Hyde, and G. L. Xie, 2012 Cytology and ultrastructure of interactions between Ustilago esculenta and Zizania latifolia.

685 Zhang, Y., Q. Cao, P. Hu, H. Cui, X. Yu et al., 2017 Investigation on the 686 differentiation of two Ustilago esculenta strains - implications of a relationship 687 with the host phenotypes appearing in the fields. BMC Microbiol. 17: 228. 
690

691

692

693

694

695

696

697

698

699

700

701

702

703

704

705

706

707

708

709

710

711

712

713

714

715

\section{Figure legends}

Figure 1 Water bamboo plants in the commercial field and features of each edible gall in different Taiwan varieties. (A) Red shell variety of water bamboo was cultivated in Sanchi, Taiwan. (B) Features of the red shell variety. From left to right: appearance of edible gall, gall without leaf sheath, longitudinal section of gall. (C) Features of the green shell variety. From left to right: appearance of edible gall, gall without leaves sheath, longitudinal section of gall. (D) Swelling galls with black teliospore sori. Mature galls of red shell variety collected from Sanchi show different levels of sori formation; left: sori scattered in the swelling tissue, or huashin, right: gall full of sori, or heishin.

Figure 2 Life cycle and morphological features of $U$. esculenta. (A) The life cycle of U. esculenta is associated with infection of Zizania latifolia Turcz. In the asexual cycle, $U$. esculenta grows as yeast/sporidia and reproduces asexually by budding. In the sexual cycle, two compatible sporidial cells produce conjugated filaments to fuse and generate mating hyphae. Budding yeast cells at the front parts and empty cell compartments are usually observed. Mating filaments penetrate into host plants and develop swelling galls at the basal stem, which was stimulated to grow by the disturbance of phytohormone homeostasis. Teliospore sori are then produced in the interior of mature galls. Teliospores are diploid, which gave rise to promycelium, followed by meiosis and produce four haploid yeast cells with two different mating types. (B) Teliospores collected from infected plants were induced to germinate on PDA medium. Several septa and four sporidia were observed after $20 \mathrm{hr}$. (C) $U$. esculenta sporidia existed as single or multiple yeast formed cells. (D) DAPI staining of sporidia in sample (C) revealed a single nucleus in each cell. (E) Two compatible haploid sporidia conjugated to produce mating hypha (red arrow). (F) DAPI and CFW 
716 staining of sample (E) show the positions of nuclei and septa. (G) Mating hyphae of $U$.

717 esculenta were characterized by empty cell compartment (red arrow). The right top 718 was the direction of hyphal growth. (H) DAPI and CFW staining of sample (G) show 719 both mononuclear and binuclear cells at the front end. Monokaryons and dikaryons 720 are indicated with white and yellow arrows, respectively.

722 Figure 3 Mating assay of U. esculenta isolates derived from the meiotic progenies of 723 teliospores. (A) Mating assay of the 4 meiotic progenies of teliospore 12JK1RB1_A.

724 Four of 6 pairs showed compatible results according to the production of mating 725 filaments. (B) Mating result of 8 strains germinated from two teliospores: 726 12JK1RB1_A and 12SB1RB1_B. Twelve pairs showed compatible mating. (C) Same 727 process but different results with different strains. Strains were produced from 728 teliospores 12SB1RB1_A and 12SB1RB1_B. Only 8 pairs showed compatible mating. 729 (D) Mating assay of 6 U. esculenta isolates whose mating type were determined. 730 Compatible and incompatible mating pairs were confirmed (1, 12JK1RB1-A1; 2, 731 13PJ1GB1-A3; 3， 12SB1RB1-B4; 4， 13PJ1GB1-A4; 5. 12JK1RB1-A2; 6, 732 13PJ3GB1-A1). Mating assay performed on PDA medium containing 1\% charcoal, 733 except for (D) performed on GMM medium.

735 Figure 4 Genetic structure of mating type A region in U. esculenta (12JK1RB1-A1, 736 12SB1RB1-B4, 12JK1RB1-A2) and related smut fungi. Three clusters of A-region 737 genes were identified among $U$. esculenta isolates in Taiwan and showed 738 conservation with related smut fungi. Several conserved genes, including pra 739 (pheromone receptor), mfa (mating factor/pheromone), and lga/rga (mitochondria 740 inheritance-related genes), were identified and were flanked by conserved $l b a$ and $r b a$ 741 genes. Both Ue a2 and Sw a3 have one predicted gene, annotated as a predicted open 
742 reading frame, which showed only partial similarity to other lga genes. (Uh, U. hordei;

$743 \mathrm{Ue}$, U. esculenta; Um, U. maydis; Sr, Sporisorium reilianum; Sw, S. walker; Usg,

744 Ustanciosporium gigantosporum)

745 Figure 5 Genetic structure of mating type B region in U. esculenta (12JK1RB1-A1, 746 13PJ1GB1-A4, 12JK1RB1-A2) and related smut fungi. bWest ( $b W$; blue arrow) and 747 bEast ( $b E$; green arrow) genes contained a homeodomain region (red block) and were 748 flanked by the natl and cldl genes (black arrows). Three clusters of mating type 749 B-related genes were identified among U. esculenta isolates in Taiwan. Except for 750 common $b E$ and $b W$ genes, transposons were also located in this region, comprising 751 erminal inverted repeat (TIR) (orange block) and DDE domains (light gray). Ue b3 752 had a large size and contained 5 different tandem repeats (arrow heads). Brown arrow 753 indicates repeats with several single nucleotide polymorphisms and purple arrow 754 indicates identical repeat. Identical number on the arrow indicates the same pair. The 755 dashed white box in the b3 transposon represents the inserted region as compared to 756 b1 and b2 transposons. S. relianum b1 and b2 loci carry a similar DNA transposon as 757 well. (Uh, U. hordei; Ue, U. esculenta; Um, U. maydis; Sr, Sporisorium reilianum)

759 Figure 6 The alignments and phylogenetic analysis of $m f a$ and pra genes. (A) Mfa 760 protein sequence showed a conserved region of the CAAX motif and the sequence in 761 yellow was mature pheromone protein. The protein weight matrix for alignment was 762 point accepted mutation (PAM) and the gap penalty of both pairwise and multiple 763 alignment was 5. (B) Phylogenetic analysis of mfa protein. (C) Phylogenetic analysis 764 of pra protein. Both were analyzed by the neighbor-joining method and mfa and pra 765 results were divided into 3 groups. 
767 Figure 7 Comparison of rga protein. (A) The phylogenetic tree of rga protein. Two 768 Ue rga proteins were placed in 2 different clades. (B) Comparison of rga homology 769 proteins: Ax, Anthracocystis walker; Me, Macalpinomyces eriachnes; Sc, 770 Sporisorium scitamineum; Ux, Ustilago xerochloae; Usg, Ustanciosporium 771 gigantosporum; Sw, Sporisorium walker. The phylogenetic analysis involved the 772 neighbor-joining method, and the protein matrix for alignment was PAM.

Figure 8 Syntenic comparison of mating-type chromosomes among $U$. esculenta, $U$. maydis and U. hordei. (A) Partial sequence of MAT locus in U. esculenta (UE) is syntenic with U. maydis chromosomes 5 and 1. (B) Comparison of the sequence of MAT locus between $U$. esculenta and $U$. hordei indicates that these two regions are not similar. U. esculenta MAT locus is more similar to that of $U$. maydis than chromosome 2 in $U$. hordei.

Figure 9 Sequence comparison of $U$. esculenta mating type locus and corresponding

783 region in S. reilianum. Green arrows represent mating type-related genes. Red and 784 blue shades are aligned regions where the sequence identity was greater than $70 \%$. 785 Blue indicates inverted sequence. Alignment was by NCBI-blastn with default 786 settings.

Figure 10 Mating-type screening of $U$. esculenta by multiplex PCR. (A) Three isolates with different mating types were selected to validate the primers for a1/a2/a3 and b1/b2/b3. M: $100 \mathrm{bp}$ marker; Lane 1: PCR products of a1/a2/a3. The amplified

791 fragments were designed in the pra genes and the sizes of amplicons were $457 \mathrm{bp}$ for $792 \mathrm{a} 1,315 \mathrm{bp}$ for $\mathrm{a} 2$ and $515 \mathrm{bp}$ for a3. Lane 2: PCR products of b1/b2/b3. The amplified 
793 fragments were designed in the $b E$ genes and the sizes of amplicons are $347 \mathrm{bp}$ for b1,

$794237 \mathrm{bp}$ for b2 and $477 \mathrm{bp}$ for b3. (B) Multiplex PCR screening for mating type

795 showed a2 and a3 mating types among 20 U. esculenta isolates. (C) Multiplex PCR

796 screening of the same 20 strains for b mating type showed b2 and b3 mating type and

797 no recombination.

798

799 Figure S1 Pacbio reads mapping and assembly result. (A) The average read coverage 800 of unitig_12 where the mating type locus was located. The mean coverage of 801 unitig_12 was $81.15 \mathrm{X}$. The coverage of the MAT locus was similar to other bases of 802 unitig_12. (B) Detailed read-mapping views of mating type locus. Region 1 to 4 803 represents the regions of start, lowest coverage, and middle and end site, respectively.

805 Figure S2 Sequence comparison of $U$. esculenta (UE) MAT on unitig_12 and $U$. 806 hordei (UH) MAT. Green box represents $U$. esculenta MAT with parts of the 807 sequence showing synteny to UH chromosome 2. This region in UH is dense but is 808 scattered in UE. The quantity of the repetitive sequence is shared between sex 809 chromosomes. 
bioRxiv preprint doi: https://doi.org/10.1101/384727: this version posted August 4, 2018. The copyright holder for this preprint (which was not certified by peer review) is the author/funder. All rights reserved. No reuse allowed without permission.

Figure
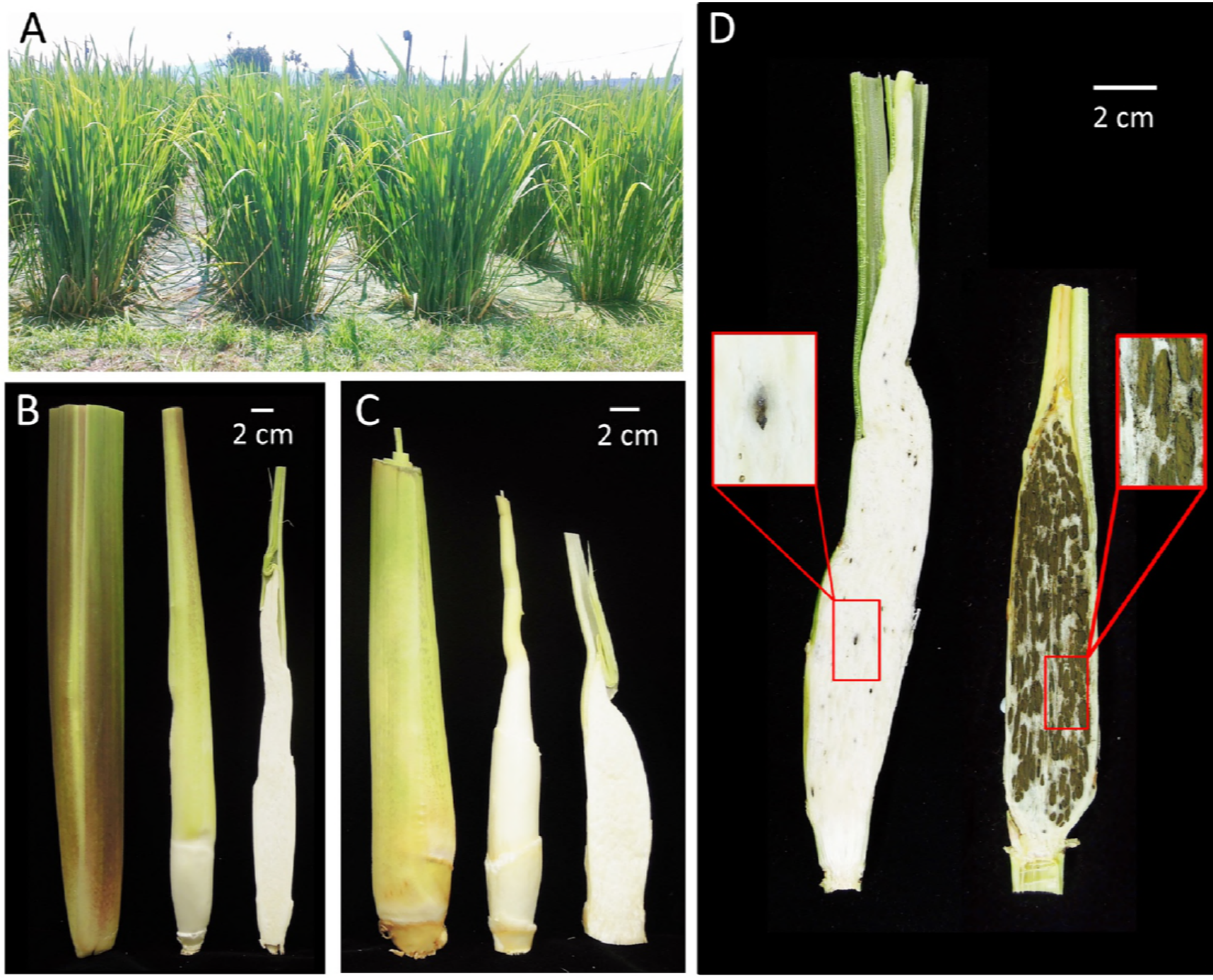

Figure 1 

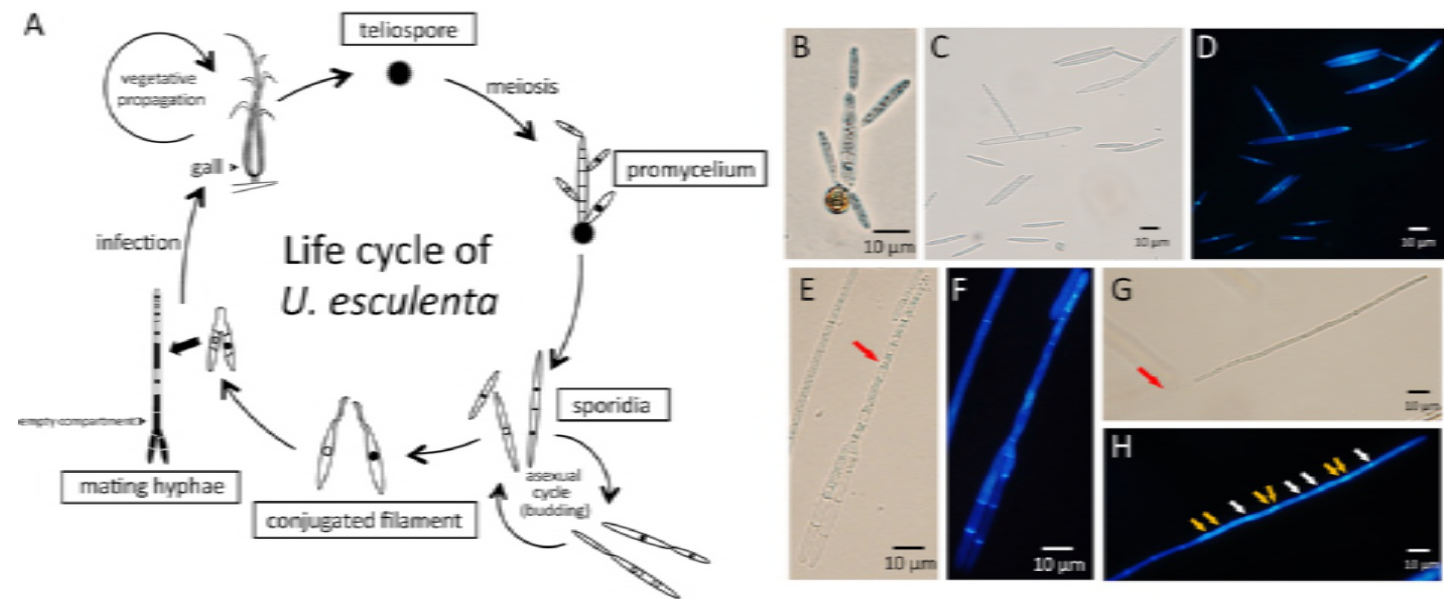

Figure 2 

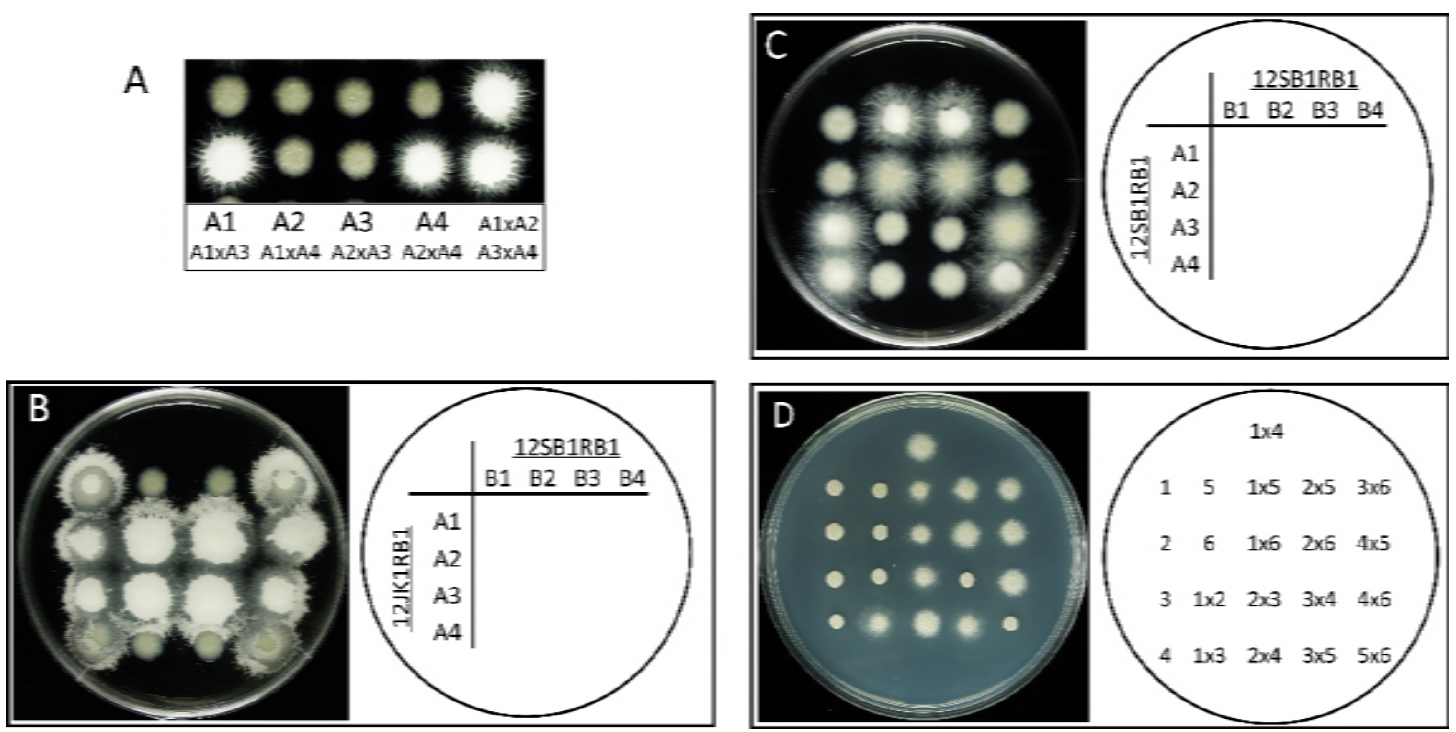

Figure 3 


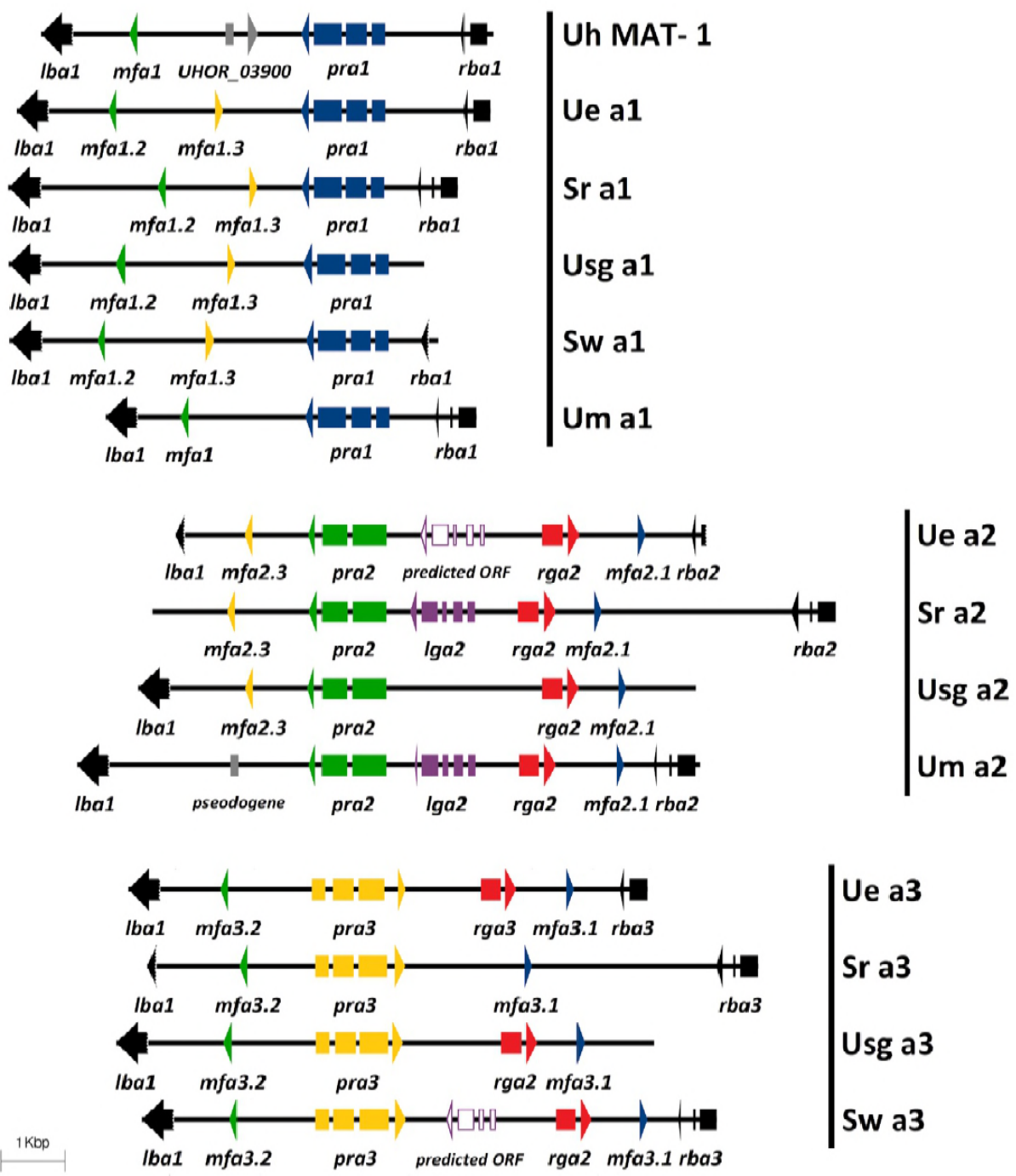

Figure 4 


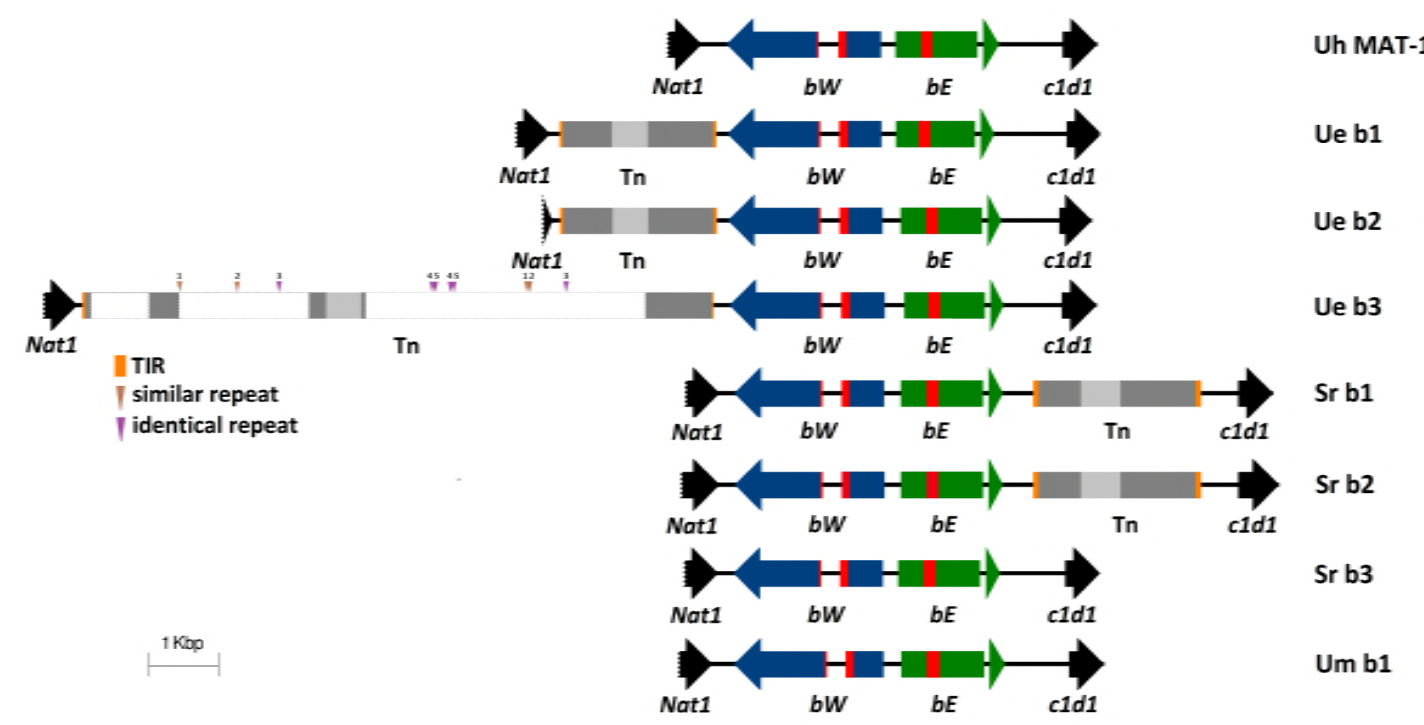

Figure 5 
bioRxiv preprint doi: https://doi.org/10.1101/384727; this version posted August 4, 2018. The copyright holder for this preprint (which was not certified by peer review) is the author/funder. All rights reserved. No reuse allowed without permission.

A

Sr_mfa2.1 M- - - F I FE S V VASVQAVS-VAEQDQT P VSE--GRGRPAVY - C T I A Sr_mfa3.1 M - - - F I F E T V VAS V Q A V S - VAEQEQT P V S E - - G R G K P A V - C T I A Ue_mfa2.1 M- - F T I F T VATAVQAAISVAEHEQAPQNE--GRGQLANY - C V VA

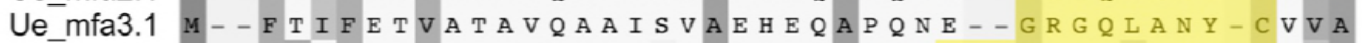
Uh_mfa2 M- - F S LFETVAAAVKVS-AAEPEAPTNE--GKGEPAPY-CIIA Um_mfa2 M- - L S I FE TVAAAAPVTV--AETQQASNNE--NRGQPGYY - C L I A

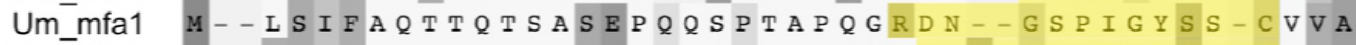
Uh_mfa1 M - - F S I F A P A T S V S T Q ES P A H G A P GKS GS G G Y T - C V A A Ue_mfa1.2 M- - F S I T QPAQS S V E T QPSPADE-GRGG--GAPLG Y T - C I V A Ue_mfa3.2 M- - F S I T Q H Q TS VSETQPSPADE-GRGG--GAPLGYST-CVIA Sr_mfa1.2 M - - F S I F Q T I Q TSASEPQQSPADE-GRGGKNGAPIG Y S - C T I A Sr_mfa3.2 M- - F S I F T T I Q T A S P Q Q S P D E - GRG GKNGA I G Y S - C T I A Ue_mfa2.3 M - - F A I F S F I N S A V S - T E Q A P V DQ-ERPD--QRTF P W S G C I A Ue_mfa1.3 M D A T L F A I S VAAVS-TEQAPVDQ-ERP D - Q R T F P S S G C I A Sr_mfa1.2 M DALTLFAPVSLGAVA-TEQAPVDE-ERPN- - R Q T F P W G - C V VA Sr_mfa2.3 M D A L T L F P V S L G A V - T E Q A P V HE - ERPN- R Q T F P I G - C V V A

B

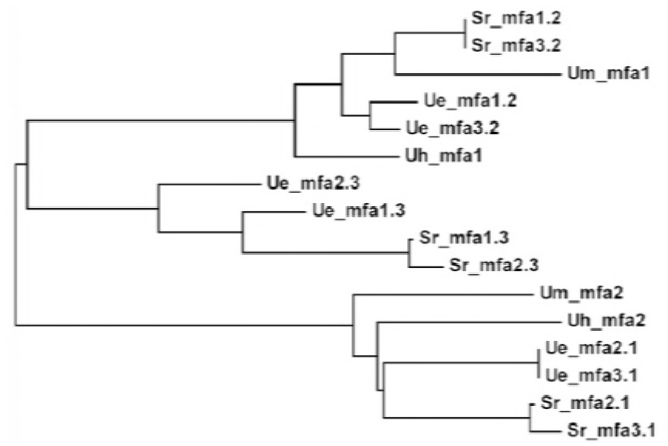

$\stackrel{\longmapsto}{0.1}$
C

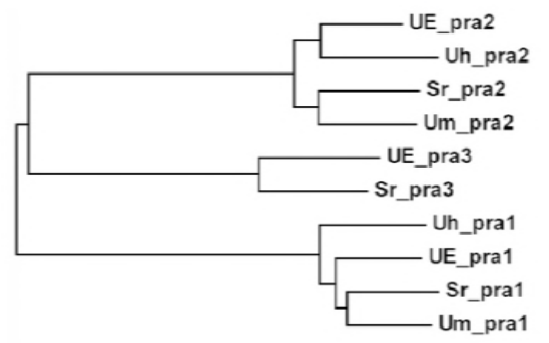

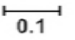

Figure 6 
bioRxiv preprint doi: https://doi.org/10.1101/384727; this version posted August 4,2018. The copyright holder for this preprint (which was not certified by peer review) is the author/funder. All rights reserved. No reuse allowed without permission.

A

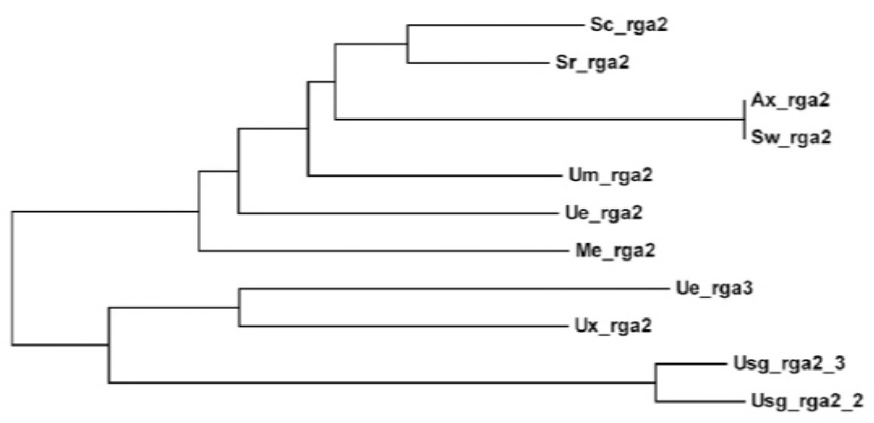

B

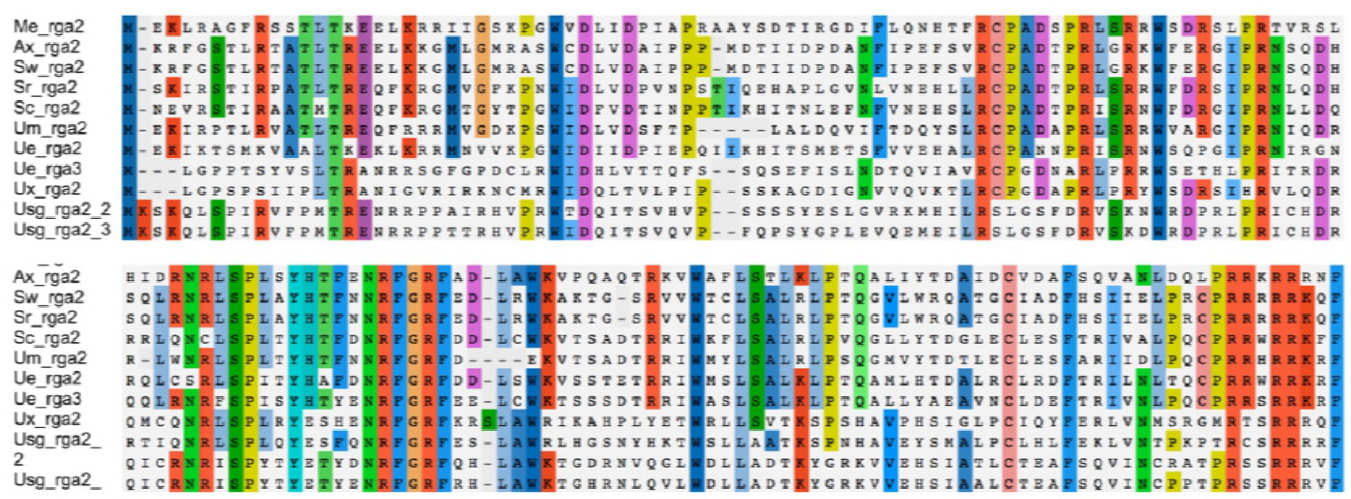

Figure 7 
A

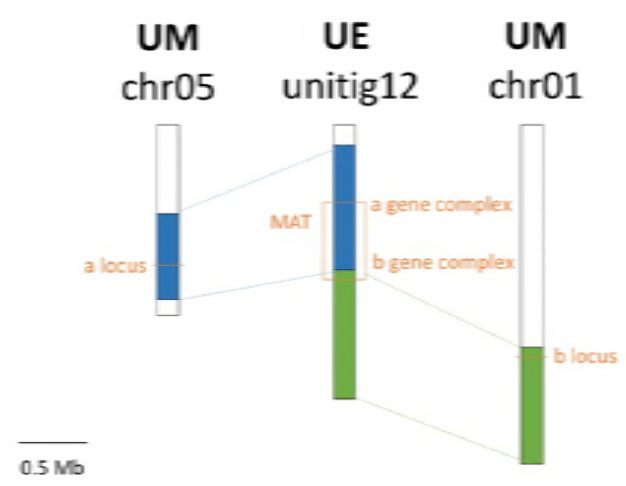

B

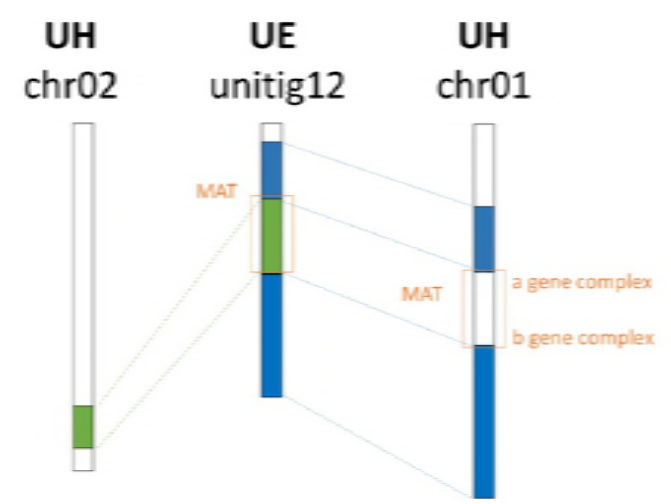

Figure 8 


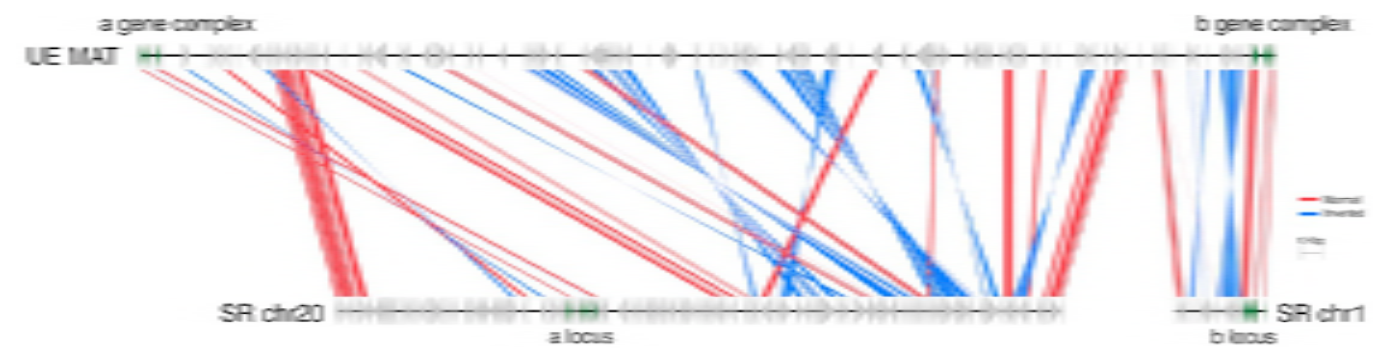

Figure 9 
bioRxiv preprint doi: https://doi.org/10.1101/384727; this version posted August 4, 2018. The copyright holder for this preprint (which was not certified by peer review) is the author/funder. All rights reserved. No reuse allowed without permission.
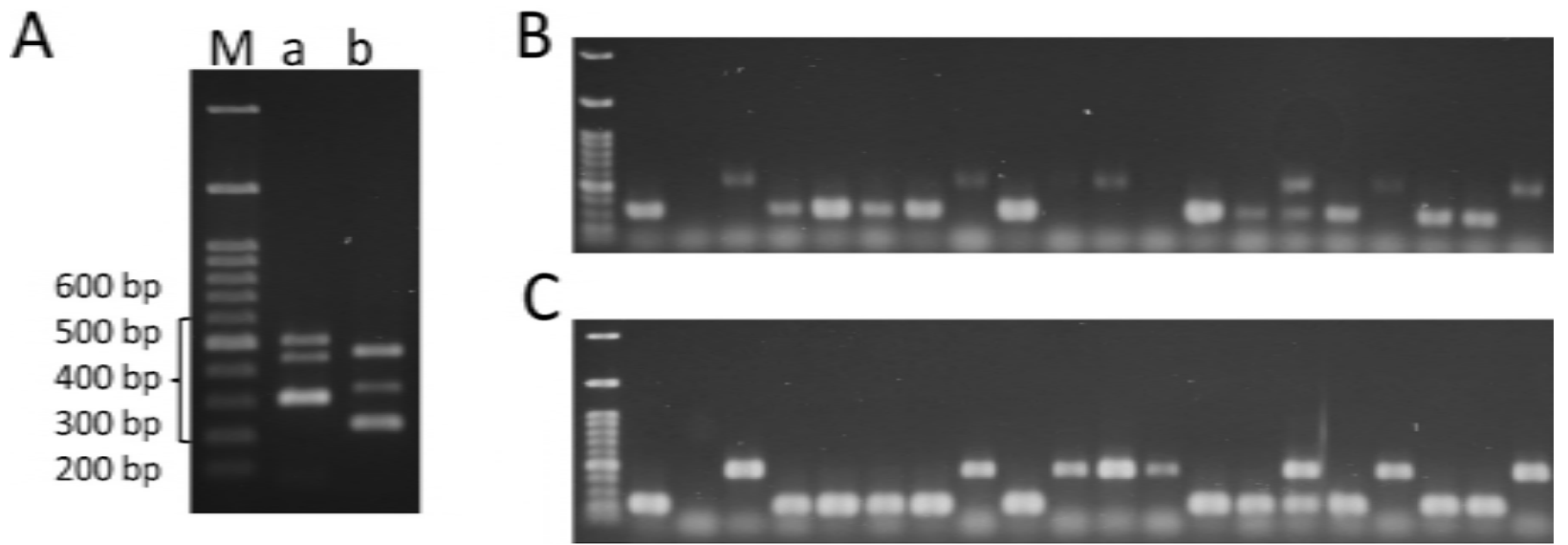

Figure 10 


\section{Supplemental data}

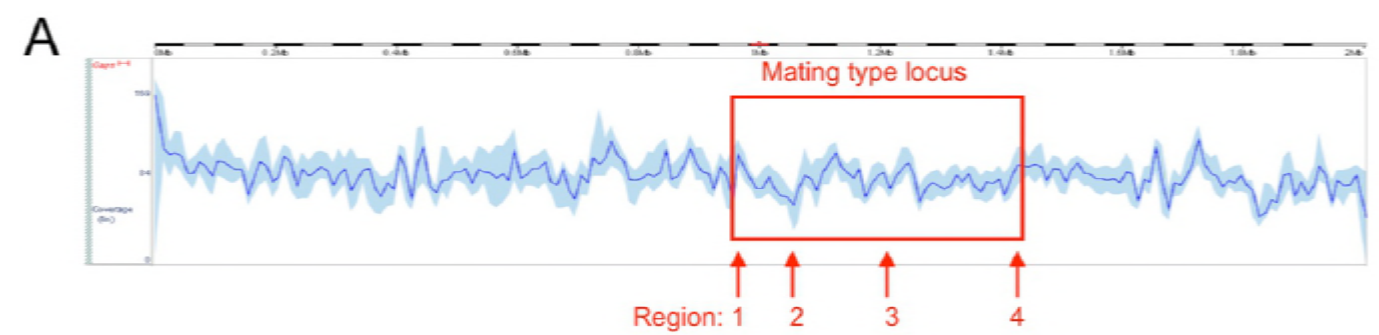

B

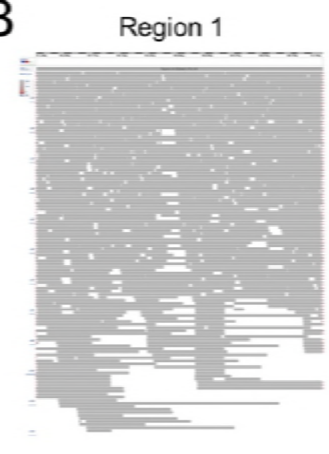

Region 2

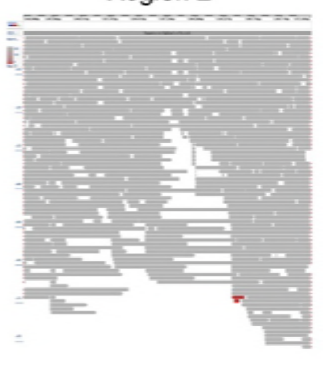

Region 3

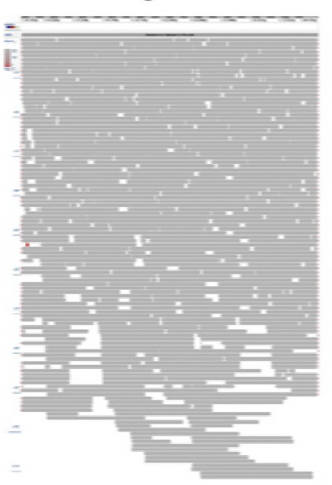

Region 4

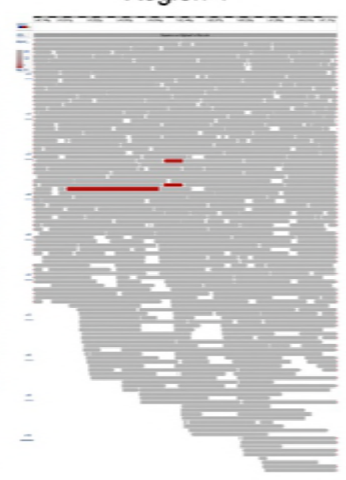

Figure S1 
bioRxiv preprint doi: https://doi.org/10.1101/384727; this version posted August 4,2018. The copyright holder for this preprint (which was not certified by peer review) is the author/funder. All rights reserved. No reuse allowed without permission.

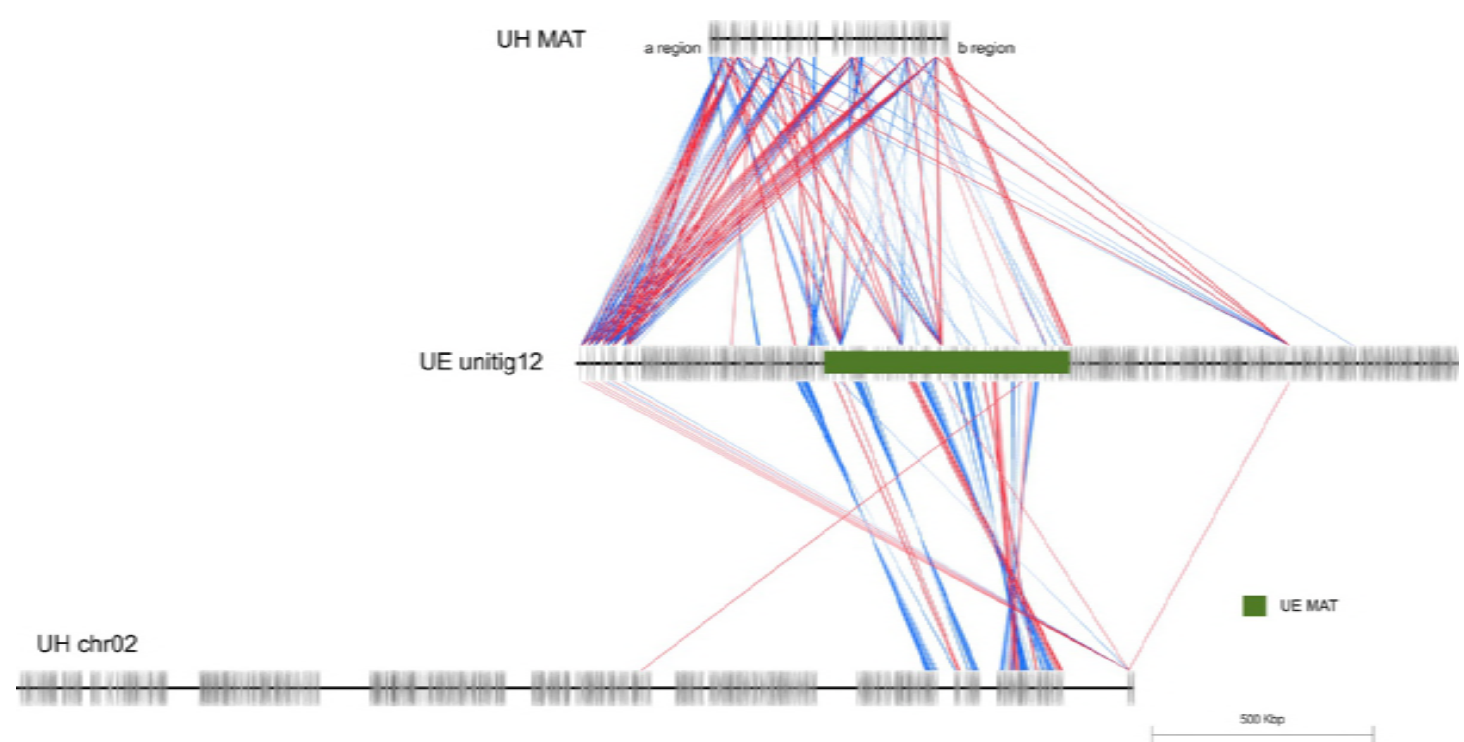

Figure S2 
Table 1 Mating assay of inter- and intra-crossing of 6 sets of teliospore-derived strains

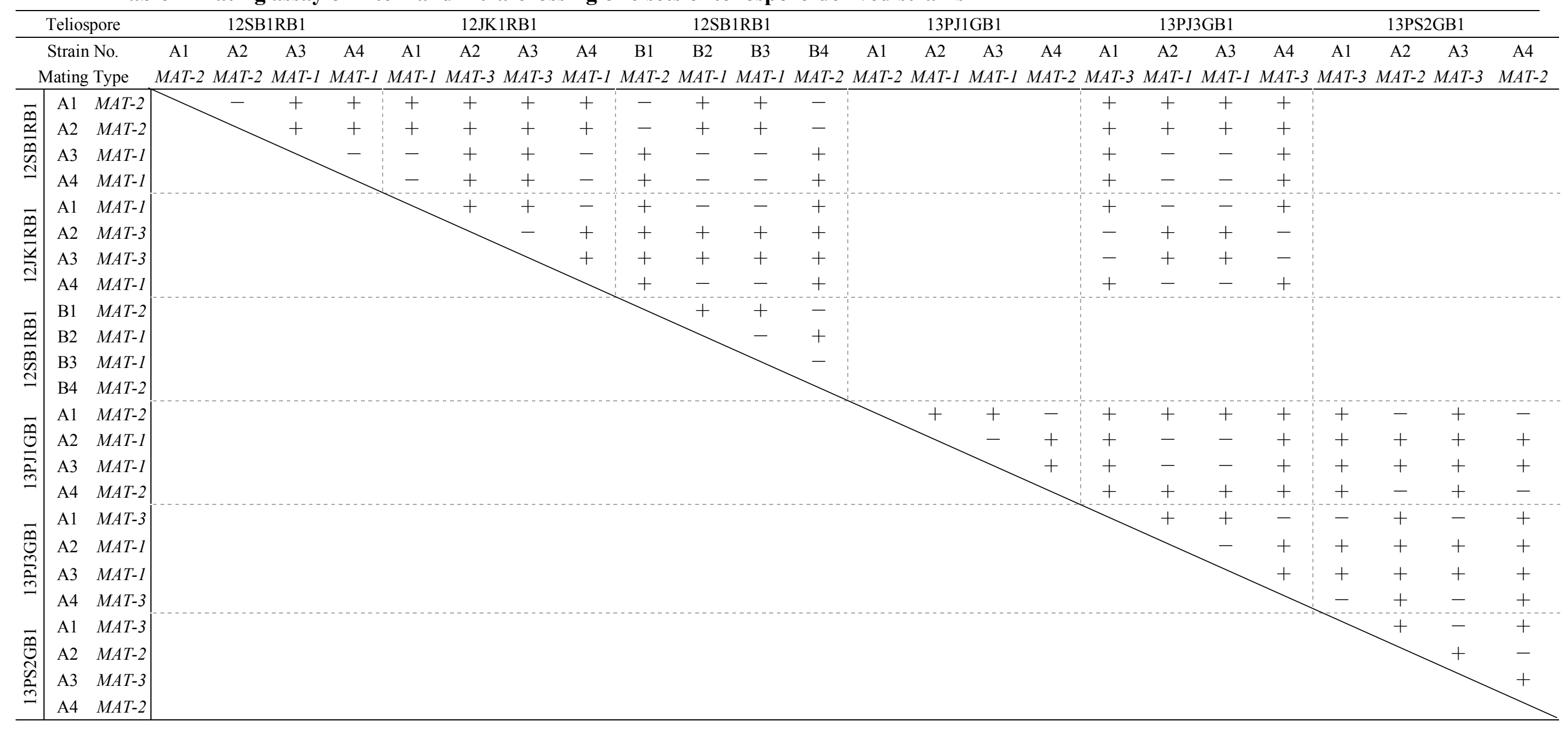

+: compatible crossing; - : incompatible crossing 
bioRxiv preprint doi: https://doi.org/10.1101/384727; this version posted August 4,2018. The copyright holder for this preprint (which was not certified by peer review) is the author/funder. All rights reserved. No reuse allowed without permission.

Table 2 Mating type screening of sexual progenies from the teliospores of two independent inoculated plants

\begin{tabular}{|c|c|c|c|c|c|c|}
\hline \multirow{3}{*}{ Idiomorph } & \multicolumn{4}{|c|}{$\begin{array}{c}13 \mathrm{PJ} 3 \mathrm{~GB} 1-\mathrm{A} 2 \\
(\mathrm{a} 1 \mathrm{~b} 1)\end{array} \underset{13 \mathrm{PJ} 3 \mathrm{~GB} 1-\mathrm{A} 4}{(\mathrm{a} 2 \mathrm{~b} 2)}$} & \multicolumn{2}{|c|}{$\begin{array}{c}\text { 13PS2GB1-A3 } \\
(\mathrm{a} 2 \mathrm{~b} 2)\end{array} \underset{13 \mathrm{PS} 2 \mathrm{~GB} 1-\mathrm{A} 4}{(\mathrm{a} 3 \mathrm{~b} 3)}$} \\
\hline & \multicolumn{2}{|c|}{ Micromanipulator } & \multicolumn{2}{|c|}{ Spreading Plate } & \multicolumn{2}{|c|}{ Spreading Plate } \\
\hline & Number & Percentage & Number & Percentage & Number & Percentage \\
\hline alb1 & & & & & 12 & $57 \%$ \\
\hline $\mathrm{a} 2 \mathrm{~b} 2$ & 29 & $50 \%$ & 234 & $57 \%$ & & \\
\hline a3b3 & 29 & $50 \%$ & 174 & $43 \%$ & 9 & $43 \%$ \\
\hline total & 58 & & 408 & & 21 & \\
\hline
\end{tabular}


Table S1 Collections of water bamboo in Taiwan

\begin{tabular}{|c|c|c|c|}
\hline Location & Cultivar & Stem type & Collection \\
\hline Sanzhi & red shell & heishin & 12SB1RB \\
\hline Sanzhi & red shell & huashin & 12SB1RF \\
\hline Sanzhi & red shell & heishin & 12SF1RB \\
\hline Sanzhi & red shell & heishin & 12SP1RB \\
\hline Sanzhi & red shell & heishin & 12ST1RB \\
\hline Sanzhi & red shell & heishin & $13 \mathrm{~S} 1 \mathrm{RB}$ \\
\hline Sanzhi & red shell & huashin & $13 \mathrm{~S} 1 \mathrm{RF}$ \\
\hline Sanzhi & red shell & huashin & $13 \mathrm{~S} 2 \mathrm{RF}$ \\
\hline Sanzhi & red shell & huashin & $13 \mathrm{~S} 3 \mathrm{RF}$ \\
\hline Sanzhi & red shell & heishin & 13SS1REB \\
\hline Sanzhi & red shell & huashin & 13SS1REF \\
\hline Sanzhi & red shell & Baishin & 13SS1REW \\
\hline Sanzhi & red shell & heishin & 13SS2RIB \\
\hline Sanzhi & red shell & huashin & $13 \mathrm{SS} 2 \mathrm{RIF}$ \\
\hline Sanzhi & red shell & heishin & 13SS3RLB \\
\hline Sanzhi & red shell & huashin & 13SS3RLF \\
\hline Sanzhi & green shell & heishin & 13SS4GEB \\
\hline Sanzhi & green shell & huashin & 13SS4GEF \\
\hline Sanzhi & green shell & heishin & 13SS5GLB \\
\hline Sanzhi & green shell & huashin & 13SS5GLF \\
\hline Jinshan & red shell & heishin & 12JK1RB \\
\hline Jinshan & red shell & heishin & 12JM1RB \\
\hline Jinshan & red shell & huashin & 12JY1RF \\
\hline Jinshan & red shell & heishin & 12JW1RB \\
\hline Jinshan & red shell & heishin & 12JT1RB \\
\hline Taoyuan & Taoyuan No.1 (red shell) & huashin & 13TO1R1F \\
\hline Taoyuan & Taoyuan No.1 (red shell) & heishin & 13TN1R1B \\
\hline Taoyuan & Taoyuan No.1 (red shell) & heishin & 13TD1R1B \\
\hline Taoyuan & Taoyuan No.2 (red shell) & heishin & 13TO1R2B \\
\hline Taoyuan & Taoyuan No.2 (red shell) & heishin & 13TN1R2B \\
\hline Taoyuan & Taoyuan No.2 (red shell) & heishin & 13TD1R2B \\
\hline Puli & green shell & heishin & 13PJ1GB \\
\hline Puli & green shell & heishin & 13PJ2GB \\
\hline Puli & green shell & heishin & 13PJ3GB \\
\hline Puli & green shell & heishin & 13PJ4GB \\
\hline Puli & green shell & heishin & 13PJ5GB \\
\hline Puli & green shell & heishin & 13PJ6GB \\
\hline Puli & green shell & heishin & 13PS1GB \\
\hline Puli & green shell & heishin & 13PS2GB \\
\hline Puli & green shell & heishin & 13PS3GB \\
\hline
\end{tabular}


Table S2 Strains isolated from germinated teliospores of $U$. esculenta

\begin{tabular}{|c|c|c|c|c|c|c|c|c|c|c|c|}
\hline Location & Cultivar & Collection & Stem type & & & & Isolate & nating type) & & & \\
\hline \multirow{5}{*}{ Sanzhi } & \multirow{2}{*}{ red shell } & \multirow{2}{*}{ 12SB1RB } & \multirow{2}{*}{ Heishin } & 12SB1RB1-A1* & $(M A T-2)$ & 12SB1RB1-A2* & $(M A T-2)$ & 12SB1RB1-A3* & $(M A T-1)$ & 12SB1RB1-A4* & $(M A T-1)$ \\
\hline & & & & 12SB1RB1-B1 & $(M A T-2)$ & 12SB1RB1-B2 & $(M A T-1)$ & 12SB1RB1-B3 & $(M A T-1)$ & 12SB1RB1-B4 & $(M A T-2)$ \\
\hline & \multirow{2}{*}{ early red shell } & 13SS1REB1 & \multirow{2}{*}{ Heishin } & 13SS1REB1-B1 & $(M A T-2)$ & 13SS1REB1-B2 & $(M A T-2)$ & 13SS1REB1-B3 & $(M A T-2)$ & 13SS1REB1-B4 & $(M A T-1)$ \\
\hline & & 13SS2REB2 & & 13SS1REB2-A1 & $(M A T-1)$ & 13SS1REB2-A3 & $(M A T-2)$ & 13SS1REB2-B1 & $(M A T-2)$ & 13SS1REB2-B2 & $(M A T-1)$ \\
\hline & green shell & 13SS4GEB & Heishin & 13SS4GEB1-A2 & $(M A T-2)$ & 13SS4GEB1-A3 & $(M A T-2)$ & 13SS4GEB1-B4 & $(M A T-1)$ & & \\
\hline Jinshan & red shell & 12JK1RB & Heishin & 12JK1RB1-A1 & $(M A T-1)$ & 12JK1RB1-A2 & $(M A T-3)$ & 12JK1RB1-A3 & $(M A T-3)$ & 12JK1RB1-A4 & $(M A T-1)$ \\
\hline \multirow{3}{*}{ Puli } & \multirow{3}{*}{ green shell } & 13PJ1GB & \multirow{3}{*}{ Heishin } & 13PJ1GB1-A1 & $(M A T-2)$ & 13PJ1GB1-A2 & $(M A T-1)$ & 13PJ1GB1-A3 & $(M A T-1)$ & 13PJ1GB1-A4 & $(M A T-2)$ \\
\hline & & 13PJ3GB & & 13PJ3GB1-A1 & $(M A T-3)$ & 13PJ3GB1-A2 & $(M A T-1)$ & 13PJ3GB1-A3 & $(M A T-1)$ & 13PJ3GB1-A4 & $(M A T-3)$ \\
\hline & & 13PS2GB & & 13PS2GB1-A1 & $(M A T-3)$ & 13PS2GB1-A2 & $(M A T-2)$ & 13PS2GB1-A3 & $(M A T-3)$ & 13PS2GB1-A4 & $(M A T-2)$ \\
\hline \multirow{7}{*}{ Taoyuan } & \multirow{4}{*}{ Taoyuan No.1 } & \multirow{4}{*}{ 13TN1R1B } & \multirow{4}{*}{ Heishin } & 13TN1R1B1-A1 & $(M A T-3)$ & 13TN1R1B1-A2 & $(M A T-2)$ & 13TN1R1B1-A3 & $(M A T-3)$ & 13TN1R1B1-A4 & $(M A T-2)$ \\
\hline & & & & 13TN1R1B1-B1 & & 13TN1R1B1-B2 & & & & & \\
\hline & & & & 13TN1R1B1-C1 & $(M A T-3)$ & 13TN1R1B1-C2 & & 13TN1R1B1-C3 & $(M A T-3)$ & & \\
\hline & & & & 13TN1R1B1-D1 & $(M A T-3)$ & 13TN1R1B1-D2 & $(M A T-2)$ & 13TN1R1B1-D3 & $(M A T-3)$ & & \\
\hline & \multirow{3}{*}{ Taoyuan No.2 } & \multirow{3}{*}{ 13TO1R2B } & \multirow{3}{*}{ Heishin } & 13TO1R2B1-A1 & $(M A T-1)$ & 13TO1R2B1-A2 & $(M A T-2)$ & 13TO1R2B1-A3 & $(M A T-1)$ & 13TO1R2B1-A4 & $(M A T-2)$ \\
\hline & & & & 13TO1R2B1-B1 & $(M A T-2)$ & 13TO1R2B1-B2 & $(M A T-1)$ & 13TO1R2B1-B3 & $(M A T-2)$ & 13TO1R2B1-B4 & $(M A T-1)$ \\
\hline & & & & 13TO1R2B1-C1 & $(M A T-2)$ & 13TO1R2B1-C2 & $(M A T-2)$ & 13TO1R2B1-C3 & $(M A T-2)$ & 13TO1R2B1-C4 & \\
\hline
\end{tabular}

*A1, A2, A3, A4 indicate the 4 sporidia isolated from the same teliospore; B1, B2, B3, B4 are derived from the same teliospore. 
Table S3 Strains isolated from stem tissue of water bamboo

\begin{tabular}{|c|c|c|c|c|c|c|c|c|c|}
\hline \multirow{2}{*}{$\begin{array}{c}\text { Location } \\
\text { Sanzhi }\end{array}$} & \multirow{2}{*}{$\frac{\text { Cultivar }}{\text { late green shell }}$} & \multirow{2}{*}{$\begin{array}{c}\text { Collection } \\
13 \mathrm{SS} 2 \mathrm{GLF}\end{array}$} & \multirow{2}{*}{$\frac{\text { Stem type }}{\text { Huashin }}$} & \multicolumn{6}{|c|}{ Isolate } \\
\hline & & & & 13SS2GLF1-6-1 & 13SS2GLF1-6-2 & 13SS2GLF1-6-3 & 13SS2GLF1-6-4 & 13SS2GLF1-7-4 & \\
\hline \multirow{7}{*}{ Sanzhi } & \multirow{7}{*}{ early red shell } & \multirow{2}{*}{ 13SS1REW } & \multirow{2}{*}{ Baishin } & 13SS1REW1-3-1-1 & 13SS1REW1-3-1-2 & 13SS1REW1-3-1-3 & 13SS1REW1-3-1-4 & & \\
\hline & & & & 13SS1REW1-4-1 & 13SS1REW1-4-2 & 13SS1REW1-4-3 & 13SS1REW1-4-4 & & \\
\hline & & 13SS1REF1 & \multirow{5}{*}{ Huashin } & 13SS1REF1-3-1 & 13SS1REF1-3-2 & 13SS1REF1-3-3 & 13SS1REF1-3-4 & 13SS1REF1-9-3 & 13SS1REF1-9-4 \\
\hline & & \multirow{3}{*}{ 13SS1REF2 } & & 13SS1REF2-1-1 & 13SS1REF2-1-2 & 13SS1REF2-1-3 & 13SS1REF2-1-4 & 13SS1REF2-3-1-1 & 13SS1REF2-3-1-2 \\
\hline & & & & 13SS1REF2-3-1-3 & 13SS1REF2-3-1-4 & 13SS1REF2-3-2-2 & 13SS1REF2-3-2-4 & 13SS1REF2-4-1 & 13SS1REF2-4-2 \\
\hline & & & & 13SS1REF2-4-3 & 13SS1REF2-4-4 & 13SS1REF2-8-1 & 13SS1REF2-8-2 & 13SS1REF2-8-3 & 13SS1REF2-8-4 \\
\hline & & 13SS1REF3 & & 13SS1REF3-1-1 & 13SS1REF3-1-2 & 13SS1REF3-1-3 & 13SS1REF3-1-4 & & \\
\hline \multirow{10}{*}{ Sanzhi } & \multirow{10}{*}{ red shell } & & \multirow{6}{*}{ Huashin } & 13SS1RF1-1-1 & 13SS1RF1-1-2 & 13SS1RF1-1-3 & 13SS1RF1-1-4 & 13SS1RF1-2-1 & 13SS1RF1-2-2 \\
\hline & & 13SS1RF1 & & 13SS1RF1-2-3 & 13SS1RF1-2-4 & 13SS1RF1-7-1 & 13SS1RF1-7-2 & 13SS1RF1-7-4 & 13SS1RF1-9-1 \\
\hline & & & & 13SS1RF1-9-2 & 13SS1RF1-9-3 & 13SS1RF1-9-4 & & & \\
\hline & & 13SS1RF2 & & 13SS1RF2-10-1 & 13SS1RF2-10-2 & 13SS1RF2-10-3 & 13SS1RF2-10-4 & & \\
\hline & & \multirow{2}{*}{ 13SS1RF3 } & & 13SS1RF3-4-1 & 13SS1RF3-4-2 & 13SS1RF3-4-3 & 13SS1RF3-4-4 & 13SS1RF3-7-1 & 13SS1RF3-7-2 \\
\hline & & & & 13SS1RF3-7-3 & 13SS1RF3-7-4 & 13SS1RF3-10-2 & 13SS1RF3-10-3 & 13SS1RF3-10-4 & \\
\hline & & \multirow{4}{*}{$13 \mathrm{SS} 1 \mathrm{RB}$} & \multirow{4}{*}{ Heishin } & 13SS1RB1-1-1 & 13SS1RB1-1-2 & 13SS1RB1-1-4 & 13SS1RB1-6-1 & 13SS1RB1-6-2 & 13SS1RB1-6-3 \\
\hline & & & & 13SS1RB1-6-4 & 13SS1RB1-7-1 & 13SS1RB1-7-2 & 13SS1RB1-7-3 & 13SS1RB1-7-4 & 13SS1RB1-9-1 \\
\hline & & & & 13SS1RB1-9-2 & 13SS1RB1-9-3 & 13SS1RB1-9-4 & 13SS1RB1-10-1 & 13SS1RB1-10-2 & 13SS1RB1-10-3 \\
\hline & & & & 13SS1RB1-10-4 & & & & & \\
\hline
\end{tabular}


Table S4 Primer sets of mating type A and B gene complex

\begin{tabular}{|c|c|c|c|}
\hline \multicolumn{4}{|c|}{ A gene complex } \\
\hline Primer & Sequence $\left(5^{\prime} \rightarrow 3^{\prime}\right)$ & Gene & Mating type idiomorph \\
\hline wc1476 & CAGCGCAARAAYCCCAACGG & lbal & \\
\hline wc1477 & GCATACATVGGAATCTCCCAGA & lbal & \\
\hline wc1478 & TTYGTCGCNACYATGGGCGC & panC & \\
\hline wc1479 & CCTTCCATCTGRTGRCTGAG & panC & \\
\hline wc1532 & CCTTTCATTGCTCGCCAGTG & pral & al \\
\hline wc1533 & AGAGGGCAGACGAGTCGAGAC & pral & al \\
\hline wc1540 & GGTCGACAGCCATCATTGAG & lbal & $\mathrm{al}, \mathrm{a} 2, \mathrm{a} 3$ \\
\hline wc1541 & GCCCTTGGATGTCTCTAGCG & rbal & $\mathrm{al}, \mathrm{a} 2, \mathrm{a} 3$ \\
\hline wc1542 & CCGTCCCCTGAGGCATCAAC & pra3 & a3 \\
\hline wc1543 & ACGTTCTGAACGCTCCTTGT & & a3 \\
\hline wc1545 & ACGGCGTCAAGTTGGCATTAC & & al \\
\hline wc1546 & AGTGAACCGAGCACCTCAATGC & pral & al \\
\hline wc1547 & ATCATGTATCTTGGAGCCCTGTC & pra3 & a3 \\
\hline wc1548 & GACCTGCGTGTCGTTCAAGC & rga3 & a3 \\
\hline wc1629 & GCCTCAACAACCGATGCAATG & & $\mathrm{a} 2, \mathrm{a} 3$ \\
\hline wc1630 & ATCAACGATCCGTCCACCCATC & & $\mathrm{a} 2, \mathrm{a} 3$ \\
\hline wc1644 & GGAACACACAATGCTGCAGAATAA & & a2 \\
\hline wc1645 & GAGTCCTTGTACTTGCATTGTG & & a2 \\
\hline wc1677 & CACCTCTTGAATCTTCCAAATCG & rga3 & a3 \\
\hline wc1678 & AGCGGTTCTCGTATGTATGGTA & rga2 & a2 \\
\hline wc1679 & CAAAGACGGAGCACAGGACG & pra2 & a2 \\
\hline wc1701 & GAAAAGAGGTAGGGGTTCCA & & al \\
\hline wc1702 & GTACTGACCATCAGATAAAG & & al \\
\hline wc1703 & GACTTTGAACCCTCTTGTAC & & al \\
\hline wc1704 & GGTTTCCTTCGAGTTGTCTT & & al \\
\hline wc1705 & CCTGAACGTAATTCTGAGTC & & al \\
\hline wc1709 & CGGTGTCCAAGCCCCAAGAC & & a2 \\
\hline wc1710 & AGAGCGGACAGAGATGAAAT & & a2 \\
\hline wc1721 & CAGAAAGACCGGATGCATACTC & & a2 \\
\hline wc1722 & TTTGGTTGCGACATCAGCG & pra2 & a2 \\
\hline wc1748 & GGTCTACAAGACAACGTCGTCA & pra2 & a2 \\
\hline wc1749 & AACTGGTCTGCTCCCTTATTCG & pra2 & a2 \\
\hline wc1750 & GATGCCCTTGGTTGATGACTG & pra3 & a3 \\
\hline wc1751 & GTTGTCCTCATATCCCTTTGC & pral & al \\
\hline wc1754 & ATCTCCATCGTGACAACTAGGG & & a2 \\
\hline wc1755 & GCCTTGAATCGGTCGTAGCT & & a2 \\
\hline wc1756 & AAGCCCGAACATTGCGAAG & pral & al \\
\hline wc1762 & TTCCCATCACGGTGCTCTCA & pra3 & a3 \\
\hline wc2000 & TGTCACAGCTTCAAATCCAACC & & a2 \\
\hline wc2090 & GCGTGCGTGTCCCAAATCCTTC & & a2 \\
\hline
\end{tabular}




\begin{tabular}{|c|c|c|c|}
\hline wc2348 & CCGGCTAAGATAGCGTTTGTG & & a1 \\
\hline wc2349 & GGGAGCAGAAGCAATGGACG & panC & a1 \\
\hline \multicolumn{4}{|c|}{ B gene complex } \\
\hline wc1459 & CGCTCTGGTTCATCAACG & $b E 4$ & \\
\hline wc1460 & TGCTGTCGATGGAAGGTGT & $b E 8$ & \\
\hline we1461 & CRCTVTGGTTCATYAACG & $b E 4$ & \\
\hline wc1462 & YGCTGTCVATVGAAGGTG & $b E 8$ & \\
\hline wc1474 & CTGGTTCATCAACGCGCGCCGC & $b E$ & b1, b3 \\
\hline wc1475 & TGTCGATGGAAGGTGTCTTGCT & $b E$ & $\mathrm{~b} 1, \mathrm{~b} 2, \mathrm{~b} 3$ \\
\hline wc1481 & TGGAYCTMGTKTGGATWCTGCT & cldl & $\mathrm{b} 1, \mathrm{~b} 2, \mathrm{~b} 3$ \\
\hline wc1482 & CATWGCHGGDCGCTTCKTCTTG & cldl & $\mathrm{b} 1, \mathrm{~b} 2, \mathrm{~b} 3$ \\
\hline wc1483 & GTSATGCGCGAYATYCCGGATAG & Nat1 & $\mathrm{b} 1, \mathrm{~b} 2, \mathrm{~b} 3$ \\
\hline wc1484 & GTAGTGCTGSGCGAGGTAGTAGA & Nat1 & $\mathrm{b} 1, \mathrm{~b} 2, \mathrm{~b} 3$ \\
\hline wc1511 & CTAAGCGTCTCACTCTGATCCAC & Nat1 & $\mathrm{b} 1, \mathrm{~b} 2, \mathrm{~b} 3$ \\
\hline wc1512 & CTCTACAACTTTCACCTCCGTTTC & cldl & $\mathrm{b} 1, \mathrm{~b} 2, \mathrm{~b} 3$ \\
\hline wc1523 & GTTGGTAGCAACCACTGAACTTTG & $b W 1$ & b1 \\
\hline wc1524 & CATCACTGTGGTCTCGGAAG & $b E 1$ & b1 \\
\hline wc1525 & CCTGATAGTGAGGACTGTAAG & & b1 \\
\hline wc1526 & GCATCCCAACTGAGTGCATGTAAC & & b1 \\
\hline wc1527 & AACAAGTGCATAGAGAGACCAA & & b3 \\
\hline wc1528 & GCATAGATTCTGCTCTTTGTTCT & & b3 \\
\hline wc1529 & CAGCTTGCGTGATATTGGGTGA & $b W$ & b1, b3 \\
\hline wc1530 & AAGACGACTGGGCAAGTATGATC & $b E$ & $\mathrm{~b} 1, \mathrm{~b} 2, \mathrm{~b} 3$ \\
\hline wc1531 & CGTGTGCGCTTCAGGCACTGAGA & $b E$ & $\mathrm{~b} 1, \mathrm{~b} 2, \mathrm{~b} 3$ \\
\hline wc1544 & CTACAAGGAGCACGAATCCAGGGC & & $\mathrm{b} 1, \mathrm{~b} 2, \mathrm{~b} 3$ \\
\hline wc1631 & TTGACTCAAAGGCAAGGAACGTA & Nat1 & $\mathrm{b} 1, \mathrm{~b} 2, \mathrm{~b} 3$ \\
\hline wc1632 & CTGGAAGGCTGCGTAGGAACTGC & $b W$ & $\mathrm{~b} 1, \mathrm{~b} 2$ \\
\hline wc1633 & CTCAGCCTTCGCCCTCACCTCGT & $b W 2$ & $\mathrm{~b} 2$ \\
\hline wc1635 & CAACAATCTTGAAATCGCGCC & & b2 \\
\hline wc1646 & GGTTCATGTTTGGTCAAGGTG & DDE domain & $\mathrm{b} 1, \mathrm{~b} 2$ \\
\hline wc1647 & GGCCAAAAATTGACACATCCA & DDE domain & $\mathrm{b} 1, \quad \mathrm{~b} 2$ \\
\hline wc1676 & GTTCCTGATGCACCATCCCTCC & & $\mathrm{b} 1, \mathrm{~b} 2$ \\
\hline wc1697 & GTCACAGCGCCCATTAGTC & & b2, b3 \\
\hline wc1703 & GACCCTGTTGCAGATGTTCA & & b2 \\
\hline wc1706 & GACCCTGTTGCAGATGTTCA & & b1 \\
\hline wc1707 & TAGTAACAGTAGGCATCTCG & $b W$ & b1, b3 \\
\hline wc1708 & ATGACACAGGGGTTTAAGTG & & b1 \\
\hline wc1723 & TGAGCATGGTACAGTCATTTGG & & $\mathrm{b} 1, \mathrm{~b} 2$ \\
\hline wc1742 & CGATCATTGCACGCGAACTT & $b E$ & $\mathrm{~b} 1, \mathrm{~b} 2, \mathrm{~b} 3$ \\
\hline wc1743 & CCATGAACTGTCAGAAACAC & $b E$ & $\mathrm{~b} 2$ \\
\hline wc1744 & CAGCCCGGACCTTGTACAGA & $b E$ & b3 \\
\hline wc1745 & TAAGCTGTTTGTTGTCGGAA & $b E$ & b1 \\
\hline wc1746 & AACAGCCGCTTCTTGCATAG & $b E$ & $\mathrm{~b} 2$ \\
\hline
\end{tabular}




$\begin{array}{llll}\text { wc1747 } & \text { GTCTTTCCTGTCGGCATGG } & b E & \text { b3 } \\ \text { wc1934 } & \text { ATGAGCTCTGGTCTGCCCGGTCA } & & \text { b3 } \\ \text { wc1958 } & \text { GGGTCTTGAGAAGTATGGAGCA } & \text { b3 } \\ \text { wc1959 } & \text { GCAGTGGTGGCAAACAACATTCC } & \text { b3 } \\ \text { wc1960 } & \text { GCAACATCAGGTCAGCACCATCA } & \text { b3 } \\ \text { wc1961 } & \text { GACCCTGCGACACCTACATCACA } & \text { b3 } \\ \text { wc1962 } & \text { GGGCACCTTGTCCACATGTGA } & \text { b3 } \\ \text { wc1963 } & \text { TTGATACTATTGACCCCTTCCC } & \text { b3 } \\ \text { wc1964 } & \text { CTGTAGGCAACATGATGGGGA } & \text { b3 } \\ \text { wc1965 } & \text { CTGGAGCTGGAGTACCGAGGA } & b W & \text { b3 } \\ \text { wc1966 } & \text { GAGGAGAGCTTGCTAAGTAGTAG } & & \text { b3 } \\ \text { wc1967 } & \text { AGGTACAGCCACTGCAAGGA } & \text { b3 } \\ \text { wc2087 } & \text { AGAAACCTCGTCTTCCTCGCTCCT } & \text { b3 } \\ \text { wc2088 } & \text { GAAGGGAGTGGGCTCTGGCATTG } & b W & \text { b3 } \\ \text { wc2089 } & \text { GGTCACTTGGCACATTCGTGGGAG } & \text { b3 } \\ \text { wc2174 } & \text { GCCTTCAACCACTCACCCAATATC } & \text { b1, b2, b3 }\end{array}$


Table S5 Predicted genes on the MAT-1 locus

\begin{tabular}{|c|c|}
\hline Gene & Gene description \\
\hline UE_1329 & DNA-binding protein C1D \\
\hline UE_1330 & Homeodomain transcription factor $\mathrm{bE} 1$ \\
\hline UE_1331 & B mating type protein \\
\hline UE_1332 & Related to $n$-terminal acetyltransferase 1 \\
\hline UE_1333 & Uncharacterized protein \\
\hline UE_1334 & Probable casein kinase-1 hhp1 \\
\hline UE_1335 & Probable RPN5-26S proteasome regulatory subunit \\
\hline UE_1336 & Uncharacterized protein \\
\hline UE_1337 & Uncharacterized protein \\
\hline UE_1338 & Related to MRPL33-mitochondrial ribosomal protein, large subunit \\
\hline UE_1339 & Blue copper oxidase cueO \\
\hline UE_1340 & Uncharacterized protein \\
\hline UE_1341 & Uncharacterized protein \\
\hline UE_1342 & Uncharacterized protein \\
\hline UE_1343 & Related to cell cycle arrest protein BUB2 \\
\hline UE_1344 & Glycogen synthase kinase \\
\hline UE_1345 & hypothetical protein \\
\hline UE_1346 & Cysteine proteinase \\
\hline UE_1347 & Oxysterol-binding protein \\
\hline UE_1348 & Dihydrolipoyl dehydrogenase \\
\hline UE_1349 & Related to OXA1-cytochrome oxidase biogenesis protein, mitochondrial \\
\hline UE_1350 & Uncharacterized protein \\
\hline UE_1351 & Retrovirus-related Pol polyprotein from transposon TNT 1-94 \\
\hline UE_1352 & hypothetical protein \\
\hline UE_1353 & Uncharacterized protein \\
\hline UE_1354 & Related to neutral amino acid permease \\
\hline UE_1355 & Putative uncharacterized protein \\
\hline UE_1356 & Uncharacterized protein \\
\hline UE_1357 & Uncharacterized protein \\
\hline UE_1358 & Uncharacterized protein \\
\hline UE_1359 & AlNc14C654G12340 protein \\
\hline UE_1360 & Uncharacterized protein \\
\hline UE_1361 & AlNc14C654G12337 protein \\
\hline UE_1362 & DNA polymerase \\
\hline UE_1363 & Uncharacterized protein \\
\hline UE_1364 & hypothetical protein \\
\hline UE_1365 & Putative gag-pol polyprotein \\
\hline UE_1366 & Adenylosuccinate lyase \\
\hline UE_1367 & Uncharacterized protein \\
\hline UE_1368 & Superoxide dismutase \\
\hline UE_1369 & Uncharacterized protein \\
\hline
\end{tabular}




\begin{tabular}{|c|c|}
\hline UE_1370 & Putative uncharacterized protein \\
\hline UE_1371 & Uncharacterized protein \\
\hline UE_1372 & hypothetical protein \\
\hline UE_1373 & Related to HRP1-subunit of cleavage factor I \\
\hline UE_1374 & hypothetical protein \\
\hline UE_1375 & Uncharacterized protein \\
\hline UE_1376 & Related to PEX6-peroxisomal assembly protein \\
\hline UE_1377 & AP complex subunit beta \\
\hline UE_1378 & rRNA adenine $\mathrm{N}$ \\
\hline UE_1379 & rRNA adenine $\mathrm{N}$ \\
\hline UE_1380 & Serine/threonine-protein phosphatase \\
\hline UE_1381 & DNA-directed RNA polymerase subunit beta \\
\hline UE_1382 & hypothetical protein \\
\hline UE_1383 & Uncharacterized protein \\
\hline UE_1384 & Putative uncharacterized protein \\
\hline UE_1385 & Uncharacterized protein \\
\hline UE_1386 & Related to centromere binding factor 1 \\
\hline UE_1387 & Eukaryotic translation initiation factor $5 \mathrm{~A}-2$ \\
\hline UE_1388 & C6 transcription factor \\
\hline UE_1389 & hypothetical protein \\
\hline UE_1390 & tRNA-dihydrouridine synthase \\
\hline UE_1391 & Histone chaperone ASF1 \\
\hline UE_1392 & Related to retrotransposon nucleocapsid protein \\
\hline UE_1393 & Putative uncharacterized protein \\
\hline UE_1394 & Chromosome 6, whole genome shotgun sequence \\
\hline UE_1395 & Related to CDC24-GTP/GDP exchange factor for Cdc $42 p$ \\
\hline UE_1396 & Uncharacterized protein \\
\hline UE_1397 & Putative 26S proteasome regulatory subunit Rpn 10 \\
\hline UE_1398 & Probable CCR4-NOT transcription complex, subunit 7 \\
\hline UE_1399 & Probable ubiquitin-conjugating enzyme E2 \\
\hline UE_1400 & hypothetical protein \\
\hline UE_1401 & Uncharacterized protein \\
\hline UE_1402 & Related to translation elongation factor eEF 1 , gamma chain \\
\hline UE_1403 & Related to mitochondrial intermediate peptidase \\
\hline UE_1404 & Phospholipid-transporting ATPase \\
\hline UE_1405 & Uncharacterized protein \\
\hline UE_1406 & Uncharacterized protein \\
\hline UE_1407 & Zinc finger protein 622 -like protein \\
\hline UE_1408 & 60 S ribosomal protein $\mathrm{L} 40$ \\
\hline UE_1409 & Related to Gag-pol polyprotein \\
\hline UE_1410 & Uncharacterized protein \\
\hline UE_1411 & Uncharacterized protein \\
\hline UE_1412 & Related to glutamyl-tRNA synthetase \\
\hline
\end{tabular}




\begin{tabular}{|c|c|}
\hline UE_1413 & Chromosome 5, whole genome shotgun sequence \\
\hline UE_1414 & Retrotransposon protein, putative, Ty1-copia subclass \\
\hline UE_1415 & Uncharacterized protein \\
\hline UE_1416 & Uncharacterized protein \\
\hline UE_1417 & Uncharacterized protein \\
\hline UE_1418 & Uncharacterized protein \\
\hline UE_1419 & Uncharacterized protein \\
\hline UE_1420 & hypothetical protein \\
\hline UE_1421 & Uncharacterized protein \\
\hline UE_1422 & hypothetical protein \\
\hline UE_1423 & Probable glyoxaloxidase 1 \\
\hline UE_1424 & Probable 60 S ribosomal protein $\mathrm{L} 12$ \\
\hline UE_1425 & WD40 repeat-like protein \\
\hline UE_1426 & Related to thymidylate synthase \\
\hline UE_1427 & Related to Protein transport protein Sec $24 \mathrm{C}$ \\
\hline UE_1428 & Peroxidase \\
\hline UE_1429 & Multifunctional tryptophan biosynthesis protein \\
\hline UE_1430 & Probable karyopherin beta- 1 subunit \\
\hline UE_1431 & Uncharacterized protein \\
\hline UE_1432 & Uncharacterized protein \\
\hline UE_1433 & Uncharacterized protein \\
\hline UE_1434 & hypothetical protein \\
\hline UE_1435 & Likely protein kinase \\
\hline UE_1436 & Related to Gag-pol polyprotein \\
\hline UE_1437 & Related to retrotransposon nucleocapsid protein \\
\hline UE_1438 & hypothetical protein \\
\hline UE_1439 & Uncharacterized protein \\
\hline UE_1440 & Uncharacterized protein \\
\hline UE_1441 & Left border a protein \\
\hline UE_1442 & A2-pheromone receptor Pra1 \\
\hline UE_1443 & Pantothenate synthetase \\
\hline
\end{tabular}

